\title{
Kemikteki metastatik tümörler
}

\author{
Metastatic bone tumours
}

\author{
Murat Arıkan \\ Ankara Onkoloji Eğitim ve Araştırma Hastanesi, Ortopedi ve Travmatoloji Kliniği, Ankara
}

\begin{abstract}
Kemik metastazları; akciğer, meme ve prostat gibi birçok solid kanserin uzak bölgedeki nüksünün sık görülen sonuçlarıdır. Solid tümörü olan hastaların yaklaşık $80 \%$ i hastalıkları esnasında omurga, pelvis ve extremitelerinde ağrılı metastazlarla karşılaşacaktır. [1]
\end{abstract}

Metastatik bir tümör karşımıza üç şekilde çıkabilir: 1) Kanser tanısı ile takipte olan bir hastada, kemik metastazı olasılığı dikkate alınarak bu amaçla yapılan kontroller sırasında (kemik sintigrafisi vb. ile); 2) Kanser tanısı bilinen bir hastada, ortaya çıkan ağrı, fonksiyon kayıpları veya patolojik kırık gibi şikayetlerin değerlendirilmesi sonucunda; 3 ) Bilinen herhangi bir hastalığı olmayan bir kişide birdenbire ortaya çıkan ağrı, fonksiyon kayıpları veya patolojik kırık gibi şikayetlerin değerlendirilmesi sonucunda olayın esas kaynağının başka yerdeki bir kanser olduğunun tespit edilmesi ile.

Kemik metastazlarının kesin insidansı bilinmemekle birlikte ABD'de her yıl ortalama olarak kemik metastazı olan 350 000 kişinin kaybedildiği düşünülmektedir. Bir tümör kemiğe metastaz yaptıktan sonra iyileşme şansı olmadığı kabul edilir; örneğin kemik metastazı olan meme karsinomlu hastaların ancak $20 \%$ 'si teşhisten beş yıl sonra hala hayatta kalabilmektedir. ${ }^{[2]}$ Kanser hücreleri iki türlü yayılma yolu izlemektedir: 1) lenfatik yol (tümörün olduğu organları drene eden lenf nodlarını invaze ederek etki eder); 2) hematojen yol (karaciğer, beyin, kemik ve akciğer gibi uzak organları invaze ederek etki eder). ${ }^{[3]}$ Hematojen yol en sık görülen mekanizmadır.

Genel bir bakışla; tümör dokusunun vücudun kendi immün hücrelerinin tümör bağlantılı makrofajlar, miyeloid kökenli süpresör hücreler ve regülatör $T$ hücreleri gibi hücrelerce inflamasyon ve infiltrasyona uğraması tümörün büyümesi yanında invazyon ve metastaza yol açar. Tümör gelişiminde başlangıçtan metastatik yayılıma kadar olan dönemde her aşama; tümör ve bağışıklık hücrelerinin etkileşerek sitokinler, büyüme etmenleri ve tümörün mikro yapısını şekillendiren proteazlar üretmesi ile regüle edilir. İnvazyon ve metastaz olması için neovaskülarizasyon, bazal membranın bozulması ve tümör hücrelerinin invazyonu için ekstrasellüler sıvının yeniden şekillenmesi ve kan ve lenf damarlarına akması gerekir. ${ }^{[4]}$

Anahtar sözcükler: kemik tümörleri; tümör metastazı; patolojik kırık; tümör rezeksiyon proteazları
Bone metastases are a common manifestation of distant relapse from many types of solid cancers, especially those arising in the lung, breast, and prostate. As many as $80 \%$ of patients with solid tumours will develop painful bone metastases to the spine, pelvis, and extremities during the course of their illness. ${ }^{[1]}$

Metastatic bone tumours can arise in three ways: 1) On routine follow-ups of patients with a diagnosis of cancer with a suspicion of metastasis (bone scan etc.); 2) While evaluating pain, limitataion of motion in the extremities and pathologic fracture in a patient diagnosed as having cancer; 3) Diagnosing cancer in another part of the body in patients known to be otherwise normal having acute pain, function loss, pathologic fracture.

The exact incidence of bone metastasis is unkown, but it is estimated that 350000 people die with bone metastases annually in the USA. Furhermore, once tumours metastasize to bone, they are usually incurable: only $20 \%$ of patients with breast cancer are still alive after five years ofthe discovery of bone metastasis. ${ }^{[2]}$ Cancer cells follow two main dissemination pathways: 1) the lymphatic pathway, leading to the invasion of the lymph nodes draining the organs where the tumour evolves; and 2) the blood pathway, leading to the invasion of distant organs such as liver, brain, bone or lung. ${ }^{[3]}$ Haematogenous pathway is the most common mechanism.

In particular, inflammation and infiltration of the tumour tissue by host immune cells, such as tumour-associated macrophages, myeloid-derived suppressor cells, and regulatory T cells, have been shown to support tumour growth in addition to invasion and metastasis. Each step of tumour development, from initiation through metastatic spread is promoted by communication between tumour and immune cells via the secretion of cytokines, growth factors, and proteases that remodel the tumour microenvironment. Invasion and metastasis require neovascularization, breakdown of the basement membrane, and remodeling of the extracellular matrix for tumour cell invasion and extravasation into the blood and lymphatic vessels. ${ }^{[4]}$

Key words: bone neoplasms; neoplasm metastasis; pathologic fracture, tumour resection proteases

- Illetişim adresi: Op. Dr. Murat Arıkan, Ankara Onkoloji Eğitim ve Araştırma Hastanesi, Ortopedi ve Travmatoloji Kliniği, Demetevler 2. Kat, Ankara Tel: 0530 - 4413151 e-posta: smuratark@yahoo.com

- Geliș tarihi: 17 Haziran 2014 Kabul tarihi: 17 Haziran 2014 


\section{KEMIK METASTAZININ GELIşiMi}

Kemiklere kan akımı parankimal organlara göre daha az olduğu için, kemik yapılar metastaza daha yatkındır. Kemiğe olan metastazlar genellikle multifokaldir ve genellikle uzun kemiklerin proksimalinde ve aksiyel iskelette (vertebra, pelvis, kaburgalar ve kraniyum) hematopoetik ilik bölgelerinde başlar. Metastatik tutulum oranları vertebrada $\% 69$ (sıklıkla anterior ve orta kolon), pelviste
$\% 41$, femurda \%25, üst ekstremitelerde \%15, kraniyumda \%14 olarak bulunmuştur (Şekil 1). ${ }^{[17]}$

Bazı kemik yayılım paternleri daha sık görülür ve bunların ortaya çıkarılması için daha fazla değerlendirme yöntemleri gerekmektedir, örneğin sekonder meme kanserleri sıklıkla çoklu aksiyel iskelet metastazları ile ortaya çıkarken, distal uzun kemik metastazları son derece nadirdir (Tablo 1).

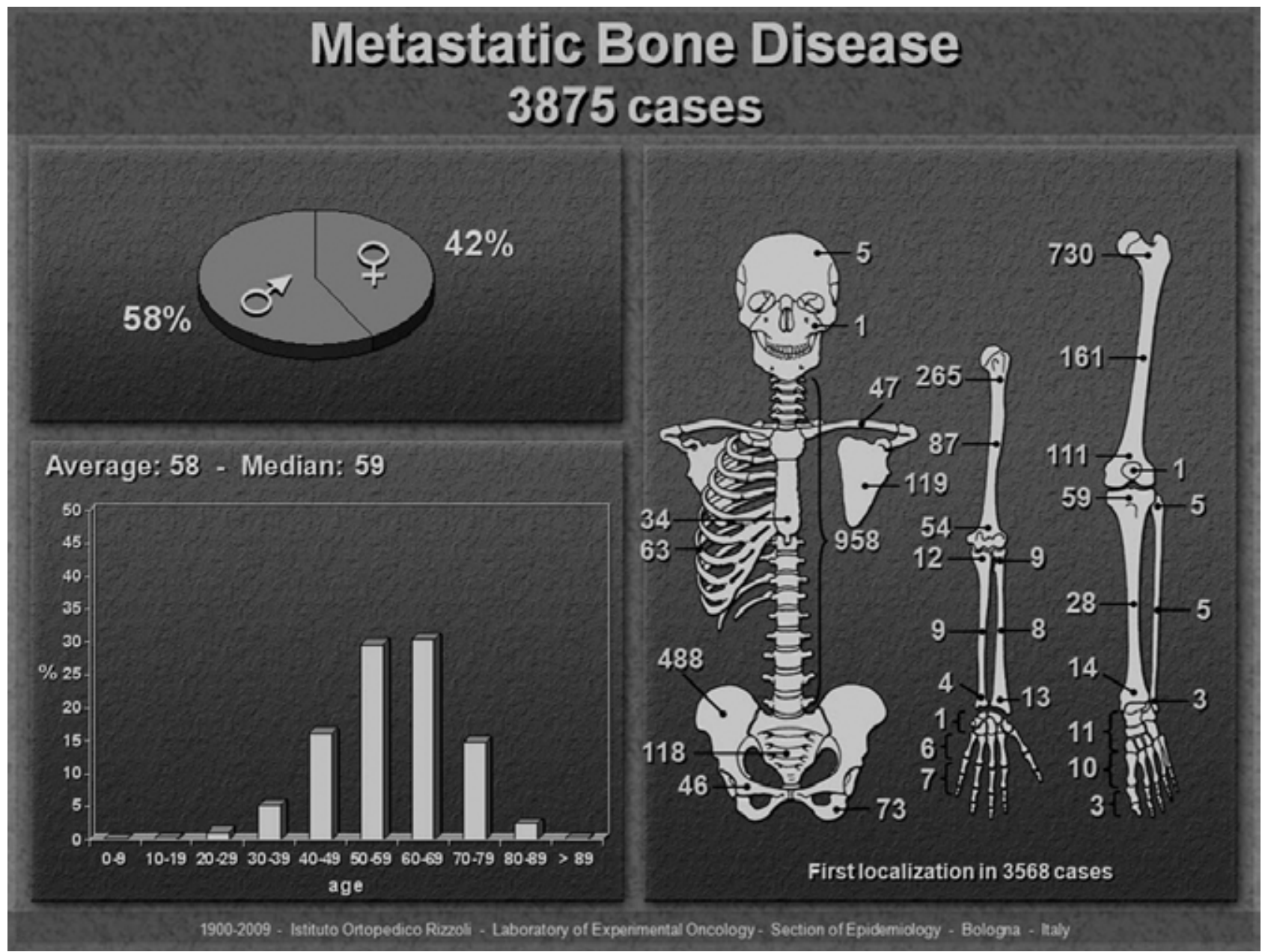

Şekil 1. Rizzoli Enstitüsü'nde yapılan ve 3875 adet kemiğe metastaz yapan olguyu kapsayan epidemiyolojik çalışmada aksiyel iskelet ve alt ekstremitenin proksimalindeki metastaz oranının daha yüksek olduğu görülmekte (1900-2009).

Tablo 1. Kemiğe metastaz yapma potansiyellerine göre düşük ve yüksek riskli tümörlerin incelenmesi

\begin{tabular}{ll}
\hline Düşük riskli tümörler & Yüksek riskli tümörler \\
\hline $\begin{array}{l}\text { Kemiğe çok nadir yayılan tümörler (sinir sistemi tümörleri, } \\
\text { yumurtalık kanseri gibi). }\end{array}$ & Kemiğe yayılmaya yatkın tümörler (prostat, meme, akciğer). \\
$\begin{array}{l}\text { Sekonder yayılım olasılığı nadir olan düşük riskli tümörler }(1 \mathrm{~cm} \\
\text { çapında veya daha küçük tümörler veya tanı anında Grade } 1 \mathrm{olan} \\
\text { tübüler karsinom gibi meme karsinomları). }\end{array}$ & $\begin{array}{l}\text { Lokal lenfoma gibi daha malign fenotip özellikleri gösteren yüksek } \\
\text { gradeli ve büyük kitleli tümör nedeniyle tedavi edilen hastalar. }\end{array}$
\end{tabular}

Yayılım özelliği olmayan tümörler (duktal karsinoma in situ gibi pre-malign olgular). 
Kemik matriksinin ve iliğinin devamlı ve dinamik dönüşüm (turnover) hali, tümör hücrelerinin sitokinler, reseptörler ve büyüme etmenleri gibi artık kaynakları kullanarak yerleşmesi ve proliferasyonu için uygun bir ortam sağlamaktadır. Metafizer bölgedeki genişlemiş sizüzoidler ve yavaş akım paterni, endotel ve tümör hücreleri arasında bir etkileşime yol açarak, kemik iliğine ilk kolonizasyon gerçekleşir. Sonrasında primer tümör tarafından üretildiği düşünülen bazı hormonal etmenler ilik hücrelerini bir takım mediyatörler (vasküler endoteliyal büyüme etmenleri) vasıtası ile premetastatik bir yuva oluşturur. Bu hücreler ise integrin ve fibronektin gibi bazı reseptör ve hücre yüzey bağları vasıtasıyla metastaz yapacak hücrelere geçirgen bir ortam sağlar (Şekil 2). Sonrasında, kemik iliğinde bulunan; Endotelin, TGF- $\beta$, IL6, IL8 gibi bazı sitokinler ve büyüme hücreleri metastatik tümörlerin büyümesini sağlarlar.

a) Primer tümörde tümör hücreleri ve lokal stroma birbirleri ile etkileşerek tümör hücre migrasyonu başlatarak bu hücreleri sistemik dolaşıma gönderirler.

b) Damar yapısına girdikten sonra tümör hücreleri konağın eritrosit, trombosit ve nötrofilleri ile etkileşerek dolaşımda hayatta kalmaya çalışırlar. c) Kemik iliğinde tümör hücreleri damarlardan (ekstravazasyon yolu ile) kaçarak, kemik iliğine doğru girerek, kemik iliğinin hücreleri ile interaksiyon sonucunda hayatta kalarak ve yerleşime geçerek, osteoklast gibi aktif hücrelere dönüşürler ve metastatik yıkılım başlar.

\section{KLINIK PREZENTASYON VE TANI}

Kemiğin metastatik lezyonlarının çoğu ya hiç semptom vermeden ya da bir karsinomun ilk evreleme çalışmasında veya takibinde rastlantısal olarak ortaya çıkar. Kemikte bir lezyonla ortaya çıkan en sık maligniteler; miyeloma, lenfoma, akciğer ve böbrek kanserleridir. ${ }^{\left[{ }^{[}\right]}$ Meme ve prostat kanserleri kemik metastazlarında en sık köken alan kanserler olmalarına rağmen, nadiren hastalığın ilk belirtisi olarak kemik metastazı ile ortaya çıkarlar. ${ }^{[6]}$ Kanser hastalarında kronik ağrıların en önemli nedeni kemik metastazlarıdır. Bu ağrı, aralıkıı ve künt bir ağrıdan, keskin, ciddi ve yayılan tarzda ağrıya kadar değişik şekillerde olabilir ve genellikle geceleri artarken, aktivite ile azalabilir. Komşu anatomik yapılara direkt infiltrasyon, kırık gelişimi ve dokulara invazyon, ağrının ilerleyici ve devamlı olmasına yol açar. Kemik metastazları, aksiyel iskelette ekstremiteye göre

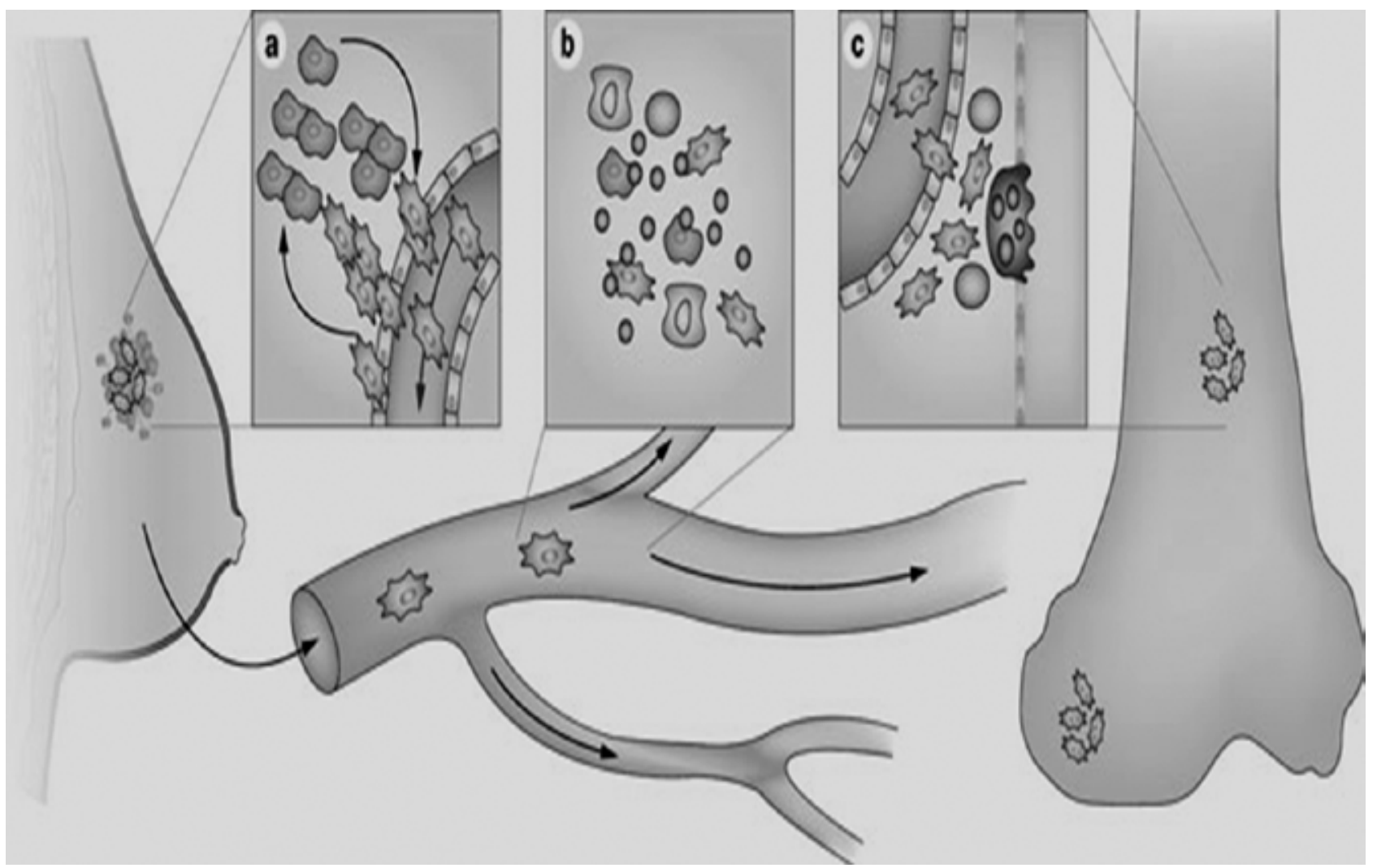

Şekil 2. Tümör hücrelerinin kemiğe metastaz evreleri. 
çok daha sık görülür. Appendiküler metastazlar ise genellikle proksimal femur başta olmak üzere alt ekstremitenin proksimal kesimlerinde görülür.

Yüksek riskli hastalarda, yeni başlayan veya artan sırt ya da bel ağrısı, kaburga ya da pelvik ağrılar, gelişen iskelet metastazının sık görülen göstergeleridir.

Daha nadir görülen semptomlar; kafa tabanı metastazlarına bağlı olarak kraniyal sinir tutulumu, kaburga veya uzun kemiklerde minimal bir travmayla veya travma olmaksızın patolojik kırık gelişmesi, sternal ağrı veya siyatalji veya sakral foraminaların tümörle sıkışmasından dolayı mesane disfonksiyonlarıdır. ${ }^{[7]}$

Vertebra metastazları, spinal korda basısına ilerleyecek kadar ciddi sonuçlar doğurabilir. Vertebra metastazlarında şikayetler, normalde hafif şiddette haftalarca devam edebilir ve paradoksal olarak erken tedavinin en etkili olduğu ve olası bir nörolojik kaybın önlenebileceği zaman dilimi bu dönemdir. Bu yüzden, vertebra metastazı açısından yüksek riskli hastalarda yürüme güçlüğü veya bacaklarda fonksiyonlarında bozulma görüldügüu anda gelişebilecek bir nörolojik defisit açısından, acil olarak manyetik rezonans (MR) görüntüleme ile spinal kord basısını ekarte etmeliyiz çünkü gelişebilecek bir parapleji ve sfinkter fonksiyon kaybının geri dönüşümsüz olma olasılığı fazladır (Şekil 3).

Spinal kord kompresyonunun akut geliştiği olgular genellikle tedaviye cevap vermeyen ve kötü sonuçlu olgulardır. Bunun nedeninin, akut başlangıçlı kord basılarında, damarsal olarak spinal kordda meydana gelen, genelde tamir edilemeyen ve metastazın tedavi ile küçültüldüğü durumlarda bile geri dönmeyen sinir hasarı olduğu düşünülür.
Kemik metastazları, ağrının dışında anemi semptomları ile ortaya çıkabilir. Yapılan tam kan analizinde, beraberinde beyaz küre ve trombositlerde de düşme olması kemik iliği tutulumunu göstermektedir ve bu durum en sık olarak ilerlemiş prostat kanserlerinde görülür. Bu hastalar genellikle pansitopeni veya yaygın damar içi koagülasyon bozuklukları sonucu kaybedilir.

Kemik spesifik alkalen fosfataz değerleri, kemik metastazlarında genellikle ilerlemiş olgularda artmış kemik yapımına bağlı olarak özellikle osteolitik olgularda veya yapımın artışına bağlı olarak osteoblastik metastazlarda artar. Hiperkalsemi ise daha nadir olarak (\%10) ve genellikle kemik metastazı olmadan paraneoplastik bir sendrom olarak, paratiroid hormon ilişkili proteinler vasıtası ile yassı hücreli akciğer kanserlerinde, meme kanserlerinde ve multipl miyelomda ortaya çıkar. Rezorbsiyon belirteçlerinden Tip 1 kollajene bağlı $N$ telopeptit kemik metastaz varlığı ve yaygınlığı ile ve prognozla yakından ilişkilidir.

Yaşlı erkek hastalarda artmış prostat spesifik antijen (PSA) değerleri, kemik metastazı konusunda şüphe doğurmakla beraber spesifik değildir. Meme karsinomlu bayan hastalarda ise kemik metastazı geliştiğinde serum CEA ve CA27 yükseklikleri görülebilir. Tümör belirteçleri, nüks takibinde ve tedavinin etkinliğinde değerli bilgiler verebilir.

Kemik metastazlarının tanısında standart yaklaşım; klinik inceleme, laboratuvar çalışmaları ve görüntüleme yöntemlerinden oluşan algoritmanın uygulanması ve bu testlerin negatif çıkması sonucunda ise biyopsi yapmaktır. Bu şekilde, birçok primer tümörün tanısı konulur. ${ }^{[8]}$ İnce iğne biyopsisi miyeloma ve lenfomaların
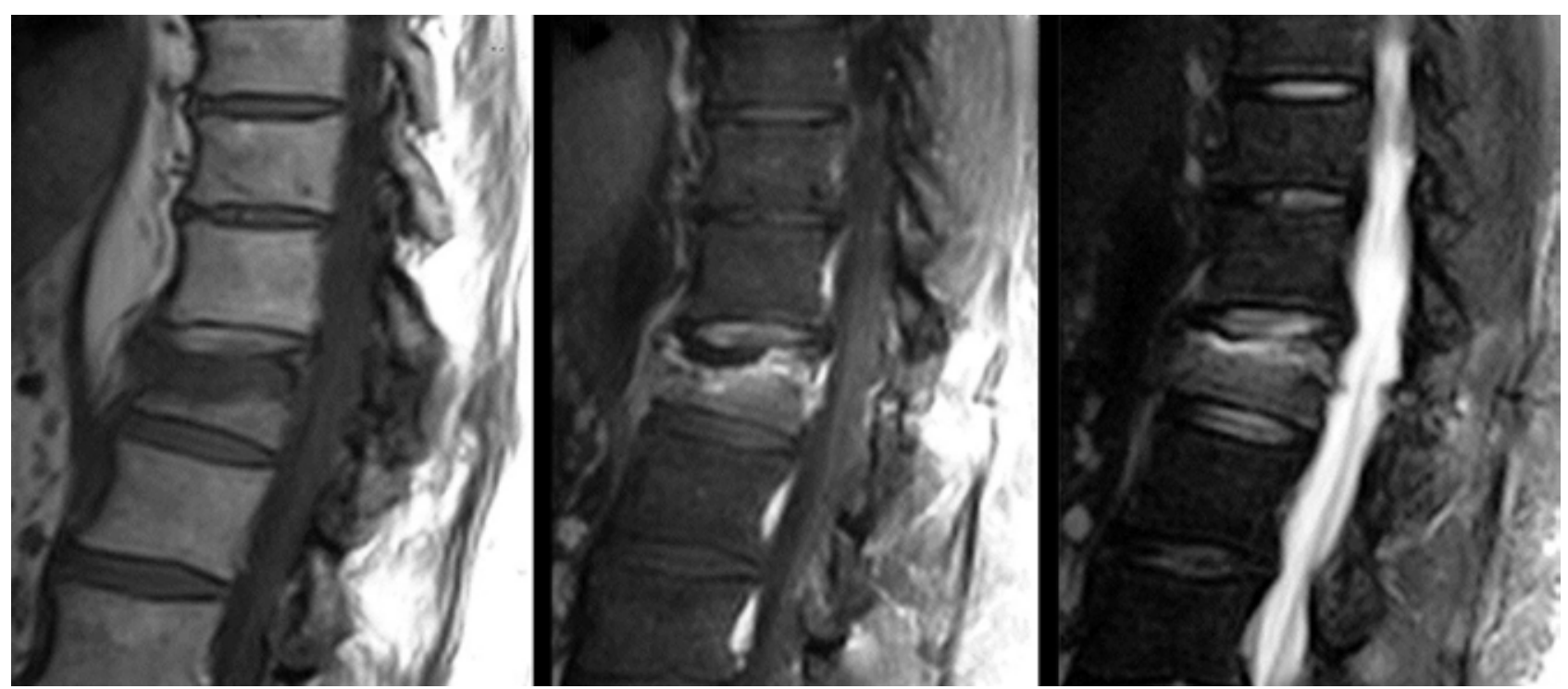

Şekil 3. Vertebral kemik iliğinde başlayıp medüller kaviteyi invaze ederek spinal kanala ulaşan bir vertebra metastazının MR görüntüsü. 
çoğunda diagnostik bir tanı aracı olacaktır ve nadiren açık biyopsiye gerek kalır. ${ }^{[9]}$ Soliter kemik lezyonu ile başvuran bir hasta primer bir sarkom tanısı düşünülerek mutlaka bir kanser merkezine yönlendirilmelidir. ${ }^{[10]}$ Daha önceden kanser öyküsü olmayan ve patolojik bir kırıkla başvuran hastalarda ise acilen yapılan bir iğne biyopsisi ise; primer karsinomların bir kısmı, hematolojik maligniteler ve az miktarda da primer sarkomlar arasında ayırım yapmada yararlı sonuçlar verir.

\section{GÖRÜNTÜLEME YÖNTEMLERi}

İskelet malignitesinden şüphelenilen tüm hastalarda, lezyonun öncelikle düz röntgen radyografileri çekilmelidir. Benign görünümlü bir lezyon bizi maligniteden uzaklaştırırken radyografik olarak agresif görünümlü soliter bir lezyon saptandığında, bilgisayarlı tomografi (BT) veya MR gibi daha ileri görüntüleme yöntemleri kullanılmalıdır. Periosteal elevasyon ve yumuşak doku yayılımı, primer kemik sarkomları için daha tipik olmasına rağmen, tek başına direkt radyografilerle primer kemik sarkomu ile metastatik kemik tümörü veya kemik iliği hücreli tümörlerin ayrımı yapılamaz. Kemik metastazından şüphenilen bir olguda grafiler; kemik destrüksiyonunu (akciğer metastazları için tipik), kemikte skleroz (prostat metastazları için tipik) veya her iki paterni bir arada (meme karsinom metastazlarında sık) gösterebilir. ${ }^{[7]}$ Grafiler, femur, tibia veya humerus gibi tek uzun kemik metastazlarında kemik kaybını ölçmek, ağrıyı geçirmek ve kırığı önlemek için yapılacak elektif cerrahi girişim açısından yol gösterici olur.

Teknesyum-99m, günümüzde kemik metastazlarını ortaya çıkarmada hem maliyet hem de etkinlik açısından en etkili yöntemdir. Kemik sintigrafisinde tespit edilen lezyonların direkt grafiyle incelenmesi ile, kombine yaklaşımla, metastazların tespitinde ve tedavinin takibinde güvenilirlik artmıştır. ${ }^{[10]}$

BT ve MR, direkt grafi ile de teyid edilen şüpheli kemik sintigrafi bulgularının değerlendirilmesinde çok etkindir. MR, aynı zamanda kemik metastazlarının kemikte sintigrafik olarak gösterilebilecek lezyonların metabolik değişiklik yapmadan önce görüntülenmesini sağladığından, çok değerli bir yöntem olarak kabul edilir. ${ }^{[11,12]} \mathrm{BT}$, özellikle vertebral metastazlarda iğne eşliğinde biyopsi alırken lezyonu odaklamada, MR ise lokal hastalı̆̆ın yayılma miktarını belirlemede ve cerrahi ve ışın tedavisini planlamada çok yararlı olur, fakat maliyeti diğer yöntemlere göre oldukça fazladır.

Kanserli hastalarda vertebraya bağlı kompresyon kırıkları sık görülür. Direkt grafiler ve kemik sintigrafileri genellikle osteoporotik veya metastatik kırık ayrımını yapmada yetersiz kalır. Bu durumda da MR çok etkili olmakla beraber, metastazla çok akut bir osteoporotik kırı̆̆ın ayrımını yapmakta sorunlar yaşanmaktadır.

\section{BiYOPSi}

Öykü, fizik muayene, rutin laboratuvar tetkikleri, ilgili kemiğin ve akciğerin iki yönlü grafisi, kemik sintigrafisi, akciğer karın ve pelvis tomografisi ile olguların \%85'inde primer tümör tanımlanabilir. Buna karşın birçok hastada iskelet metastazının kesinleşmesi için radyoterapi veya kemoterapi öncesinde biyopsi gerekir. Ince iğne biyopsisi ile yapılacak olan sitolojik inceleme birçok olguda diagnostik olur. ${ }^{[6]}$ Metastazlar, yaşıılarda en sık kemik tümörü olmaları nedeni ile en sık kemik biyopsisi gerektiren durumdur. İskelet sistemindeki her lezyondan biyopsi almak hem pratik değildir hem de gereksizdir, bu yüzden öncelikli olan ilk metastaz alanından biyopsi almaktır. İnce iğne biyopsisi kemik metastazlarında ve tümör rekürrensini göstermede çok iyi tanı yüzdesi sağlarken, primer kemik tümörünün tanısını koymada son derece yetersizdir, çünkü bu teknik dokunun mikro-mimarisini göstermez ve tümör gradesi konusunda nadiren fikir verebilir. Görüntü eşliğinde veya tek başına olmak üzere son derece kolay uygulanabilir.

Aşağıdaki durumlarda kemik metastazlarında biyopsi almadan önce tanısal tüm testlerin bitirilerek, acil şartlarda olmadan biyopsi almak gerekir:

- Lezyonun sarkom olduğu şüphesinde (bu durumda uygunsuz alınacak bir biyopsi, ekstremite koruyucu şansımızı ortadan kaldırır).

- Böbrek hücreli karsinom metastazı düşünülen olgularda (biyopsi öncesi embolizasyon yapılması kanamayı çok azaltır).

- Pozitif SPEP testi (serum protein elektroforezi) ile sistemik hematolojik maligniteler tanıda düşünülerek biyopsi gerekliliği ortadan kalkabilir.

- Primer tümörü bilinen bir hastada çoklu kemik tutulumları varlığında, tipik radyolojik görüntüler Tablo 2 ile eşleştirilerek, metastatik olarak düşünülerek davranılır ve biyopsi planlanır.

\section{KEMIĞE SIK METASTAZ YAPAN TÜMÖRLER VE ÖZELLIKLERi}

\section{Prostat}

İlerlemiş yaş, prostat kanserinde artmış risk etmenidir ve ortalama görülme yaşı 72 'dir. Ilerlemiş prostat karsinomları vücudun değişik bölgelerine, özellikle de lenf nodları ve kemiğe metastastaz yaparlar. Kemikte en sık tutulum bölgeleri; vertebra, sternum, pelvis kemikleri, kaburgalar ve femurdur. Lezyonlar \%84 oranında 
Tablo 2. Metastatik tümörlerde, primer tümörün blastik, litik veya ikisinin bir arada olduğunun bilinmesi tanıda kolaylık sağlayacaktır

\begin{tabular}{lll}
\hline Öncelikle osteoblastik & Öncelikle osteolitik & Osteoblastik-osteolitik karışık \\
\hline Prostate & Renal cell cancer & Breast cancer \\
Carcinoid & Melanoma & Gastrointestinal cancers \\
Small cell lung cancer & Multiple miyeloma & Squamous cancers at most primary sites \\
Hodgkin lymphoma & Non-small cell lung cancer & \\
Medulloblastoma & Thyroid cancer & \\
POEMS syndrome & Non-Hodgkin lymphoma
\end{tabular}

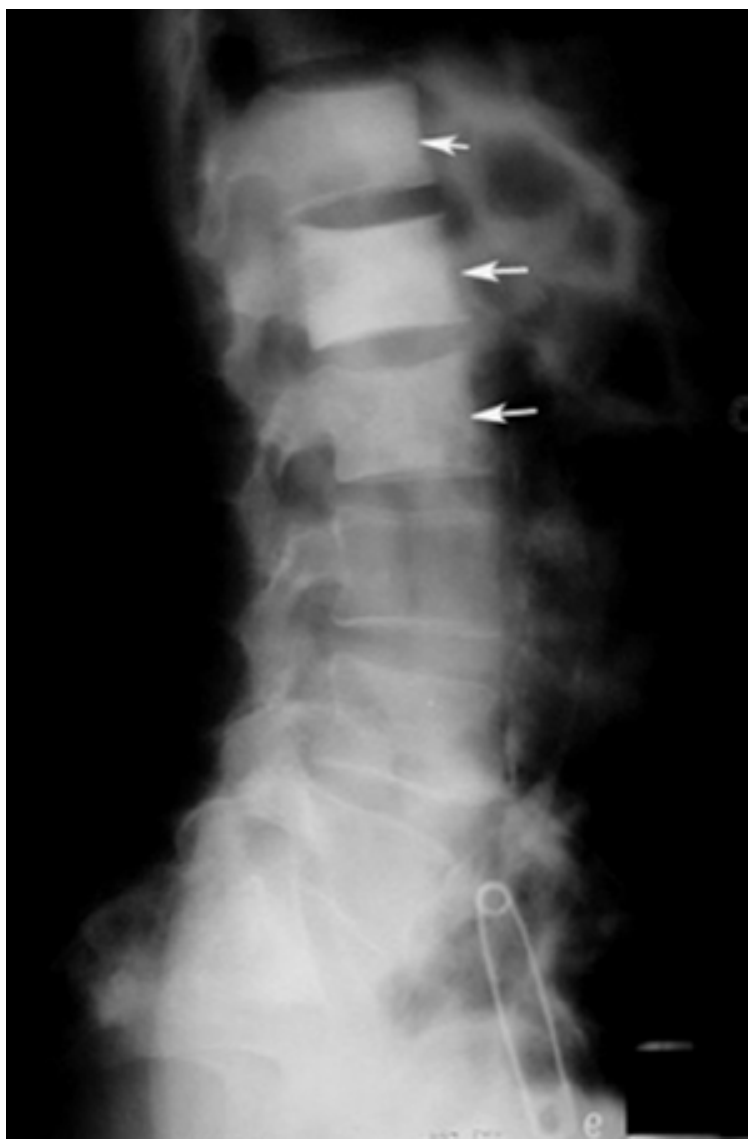

Şekil 4. Prostat karsinomuna bağlı olarak vertebra korpusunda görülen blastik metastazların direkt grafisi.

osteoblastik, \%12 karışık ve \%4 litik olarak ortaya çıkmaktadır (Şekil 4). Metastazların sklerotik olmasına bağlı olarak patolojik kırıklar nadir olarak görülmekle birlikte, yüksek kemik dönüşüm (turnover) hızına bağlı olarak tespit sonrası yüksek kaynama oranları bildirilmiştir. Prostat kanserleri, yavaş büyüyen tümörler olmalarına bağlı olarak, ancak geç dönemlerde iskelet metastazlarında spinal kord basıları ve hastanın ambulasyonuna mani olacak patolojik kırık durumlarında cerrahi tedavi gerekir. İskelet metastazı olan hastalarda bir yıllık sağkalım oranı \%47 civarındadır.

\section{Meme}

Kemikteki metastatik tutulumların en sık kaynağı memedir ve meme kanselerininde de en sık rekürrens bölgesi kemiktir. Kemik metastazları sıklıkla 40 yaş üzerindeki kadınlarda görülür. Tüm patolojik kırıkların yaklaşık \%50'si meme kanserine bağlıdır. Geçmiş yıllarda meme kanserli hastaların kemik metastazlarında prognoz çok kötü iken, günümüzde medikal ve cerrahi tedavilerdeki dramatik gelişmelerin sonucuna bağlı olarak, hastalar hem çok daha uzun hem de daha kaliteli yaşamaktadır. Kemik metastazlı üç meme kanserli hastadan ikisi kemik metastazının komplikasyonlarına bağlı olarak cerrahi, radyasyon tedavisi veya medikal tedavi alacaktır. Meme kanseri en sık patolojik kırık oluşturan tümördürve en sık olarak omurga, kaburgalar, kotsalar, pelvis ve uzun kemikler tutulur. Meme karsinomlarında olguların \%26'sında ilk tutulum bölgesi kemik olmakla birlikte olguların yaklaşık \%74'ünde iskelet tutulumu gelişmektedir. Lezyonlar; osteolitik, osteoblastik veya karışık tipte olabilir. Direkt grafilerde, birbirine karışan sklerotik ve, blastik kemik lezyonları tipiktir. Bunun dışında, saf litik, saldırgan ve destrüktif lezyonlar da görülebilir. Kemik sintigrafisi iskelet sisteminde dağılan bu lezyonları ortaya çıkarmada etkilidir; fakat bu yöntemle de tanımlanamayan lezyonları göstermede MR görüntüleme tercih edilmelidir (Şekil 5). Meme kanserli hastalarda kemik metastazları, bifosfonat tedavisi veya kemoterapi sonrası dramatik olarak iyileşebilir. Kırk yaş üstü ve meme kanseri anamnezi olan bir hastada çoklu kemik lezyonunda mutlaka öncelikle metastaz akla gelmelidir. Günümüzde, kemik metastazı yapan meme kanserlerinde sağkalım 24-36 aylara kadar çıkmıştır. 


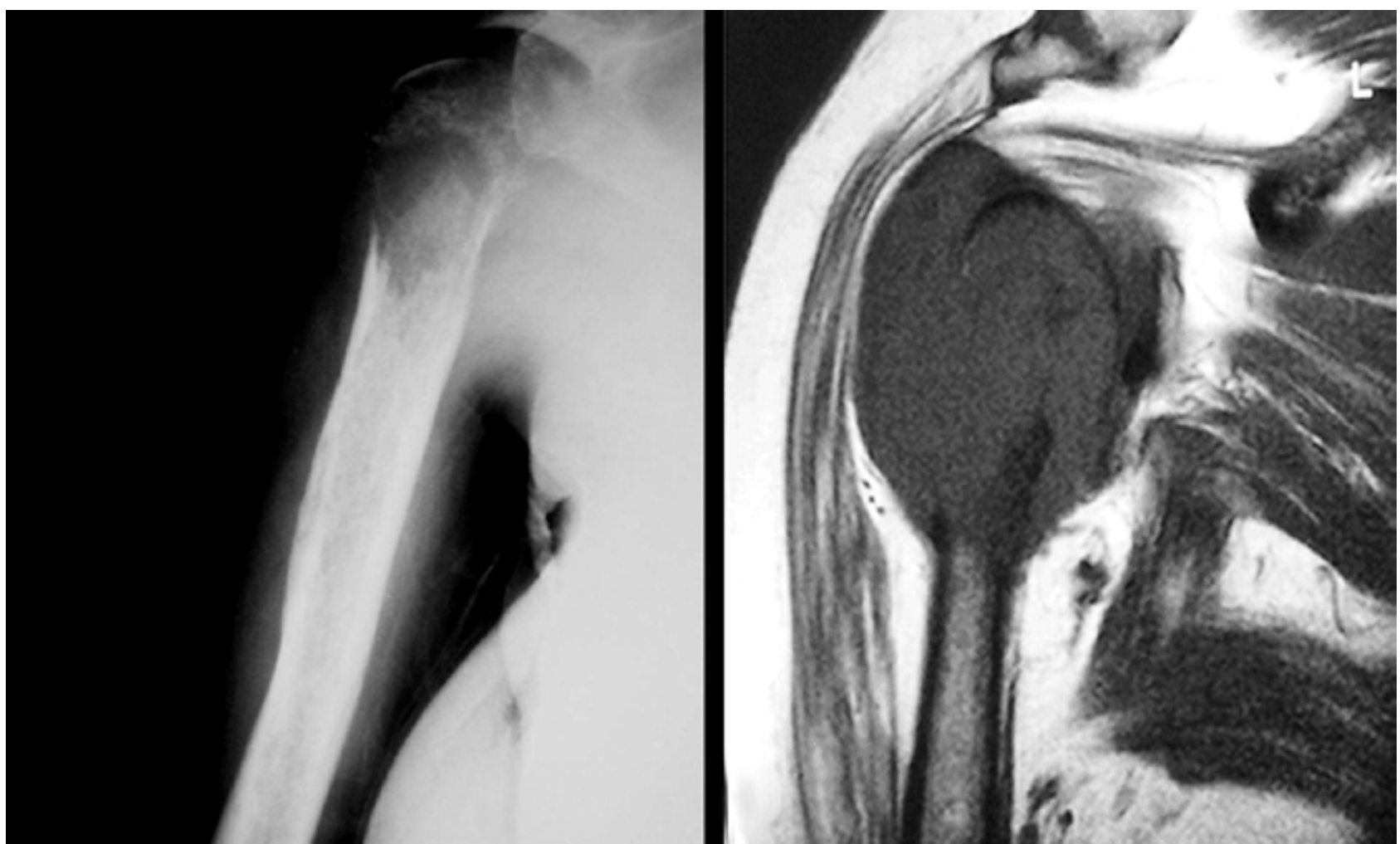

Şekil 5. Meme karsinomlu bir hastada, sağ humerus proksimalde litik tarzda metastatik tutulumun radyolojik ve MR görüntüleri.

\section{Böbrek}

Böbrek hücreli karsinomlara bağlı metastazlarda sıklık sırası: akciğer, iskelet sistemi ve beyin olarak sıralanır. Böbrek hücreli kanserler sayıca az olmalarına rağmen, tümörün kemiğe afinitesi fazla olduğundan, çok sayıda kemik lezyonuna yol açabilir. Hastaların çoğunda ağrılı kemik metastazının dışında primer lezyonuna bağlı şikayet bulunmaz çünkü kitle, karında kitle veya yan ağrısı gibi lokal semptomlar yapmadan kemiğe sıçramaktadır. Kemik metastazı tespit edilen bir olguda primer tümör bulunamadığı durumlarda mutlaka böbrek ve akciğer akla gelmelidir. Hastalar genellikle 40 yaş üzerindedir ve ortalama yaş 55'tir. Öncesinde birkaç haftalık ağrılı bir dönem olmadan patolojik gelişim riski azdır. Bazı hastalarda hiperkalsemiye bağlı sistemik belirtiler görülürken, bir kısmında da renin anjiyotensin sisteminin aktivasyonuna bağı olarak hipertansiyon kaydedilebilir. Kemikte büyük ve patlama tarzında litik lezyonlar gözlenebilir (Şekil 6). Prognozu iyi olmayan, agresif ve multiple kemik metastazları ile görülebilir.

Kemik metastazları, genellikle litik olmakla birlikte, çoğunlukla çok agresif ve kanamalı seyreder. Periosteal reaksiyon olmadan korteks kaybolabilir ve yumuşak doku şişliği sıktır. Bu lezyonlarda patolojik kırık insidansı $\% 50$ oranlarına kadar çıkar ve en sık tutulum

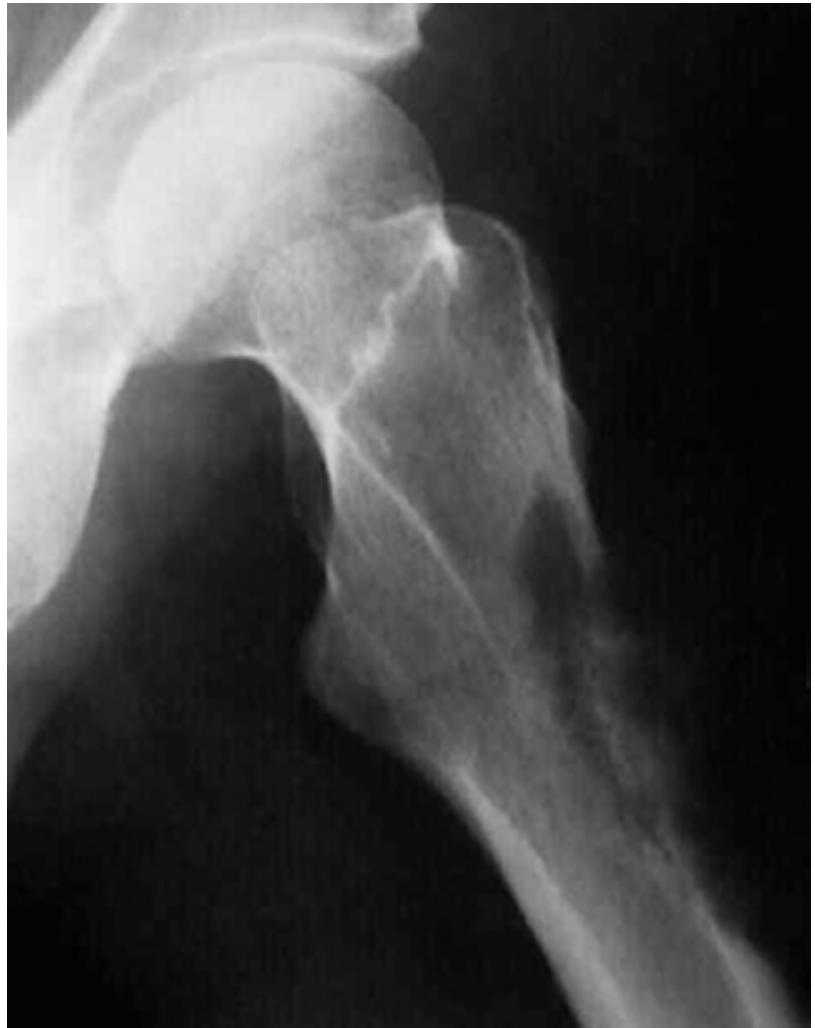

Şekil 6. Femur proksimalinde böbrek kanserine bağlı litik, destrüktif metastaz görülüyor. 
omurga ve uzun kemiklerde olur. Nadir olgularda kırıklarda spontan kaynama görülebilir. ${ }^{[13]}$ Böbrek hücreli kanser metastazlarında radyoterapi sınırlı etki sağlarken, kemoterapiden de çok yarar sağlanamaz ve ortalama sağkalım metastaz sonrası 12-18 aydır.

\section{Tiroid}

Tiroid kanser metastazları \%85 olguda iyi diferansiye (papiller, foliküler), \%10 olguda daha az diferansiye (medüller, Hurtle hücreli) ve \%5 olguda ise anaplastik tiptedir. Hastaların \%4 gibi az bir miktarında kemik metastazı gelişir. Kemik metastazları genellikle osteolitik ve çok vaskülarizedir; \%30 olguda soliter bir lezyona rastlanmaz. En sık kemik metastazı yapan tip foliküler tiroid karsinomlarıdır. Tanı anında kemik metastazı olan olgularda bile \%43 oranında uzun sağkalım olması nedeniyle, erken tanı ve uygun tedavi çok tatminkar sonuçlar verir.

\section{Akciğer}

Akciğer; meme ve prostattan sonra kemiğe en sık metastaz yapan tümördür. Sigara anamnezi çoğu zaman mevcuttur. Hastalar genellikle 40 yaş üzerindedir ve ortalama yaş 55'tir. Akciğer kanserli hastalarda da patolojik kırık öncesinde tutulan kemik bölgesinde artan bir ağrı şikayeti vardır. Hiperkalsemi ve hipertrofik pulmoner osteoartropatiye (uzun ve kısa tübüler kemiklerde ağrılı kalınlaşma ve parmaklarda çomaklaşma) bağı olarak sistemik semptomlar görülebilir. Akciğer kanserleri genellikle saf litik metastazlar yaparken, sınırı iyi belli olmayan, matriks içermeyen ve kortikal destrüksiyon içermeyen lezyonlar görülürken, blastik metastazlara da rastlanır. Günümüzde küratif bir tedavisi olmasa da, zayıflamış kemiklerde kırık gelişmeden acilen ortopedik stabilizasyon yapılmalıdır.

Küçük hücreli akciğer karsinomları ve adenokarsinomlar sıklıkla kemiğe metastaz yaparlar ve bazı olgularda el ve ayak metastazlarına da rastlanır. Lezyonlar çoğunlukla osteolitik ve \%25 olguda osteoblastiktir. Çok kötü prognozu olmakla beraber, son yıllarda sağkalım sürelerinde anlamlı bir artış sağlanamamıştır ve 5 yıllık sağkalım oranları \%2'lerde seyretmektedir.

\section{KEMIK METASTAZLARINDA PATOLOJIK KIRIK GELişiMi}

Metastatik lezyonlar, kemiğin stres dağılımı ve enerjiyi abzorbe etme kabiliyetini azaltır. Bir kemik metastazının uzun kemikte patolojik kırık geliştirme riski halen tartışmalı olmakla beraber, bazı önemli parametreler şöyle sıralanabilir:

1. Osteolitik metastazlarda blastik veya karışık tiplere göre artmış kırık riski vardır.

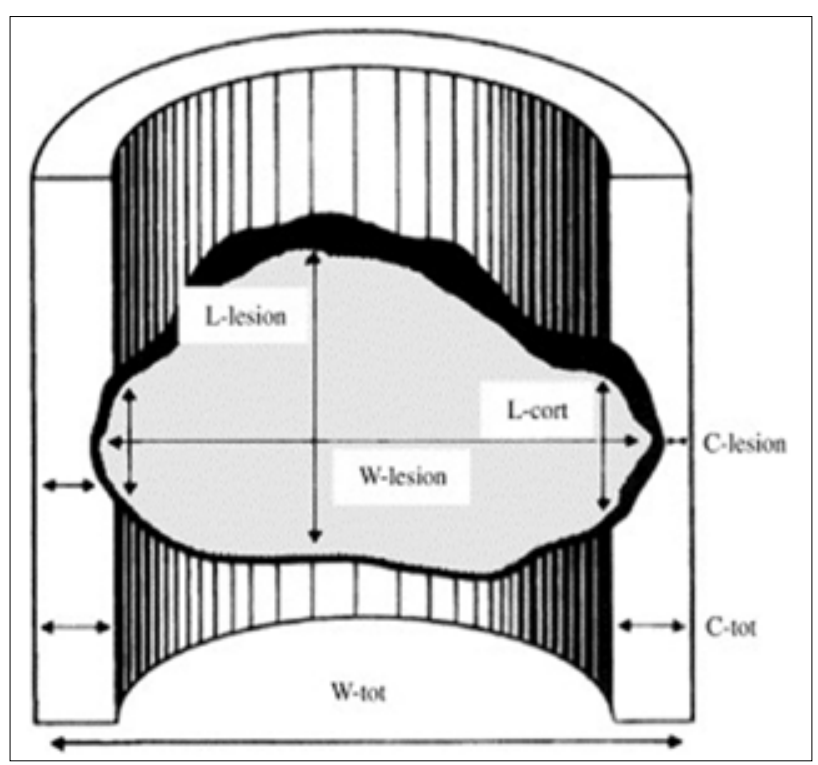

Şekil 7. Femurdaki metastatik bir lezyonun çap ölçümü (Agarawal ve arkadaşları 2006).

2. Yüksek gerilim barındıran anatomik bölgeler daha fazla kırık riski taşır, bunlara en klasik örnekler: femur boynunun tutulumu, intertrokanterik ve subtrokanterik bölge, humerusun suprakondiler bölgesi, proksimal 1/3'lük kısmı ve diyafızin orta kısmı.

3. Orijinal kemik korteksinin $\% 50-75$ oranında inceldiği endosteal veya periosteal rezorbsiyon alanları (Şekil 7).

Kemik korteksinin koronal veya longitudinal planda çapının $\% 50$ oranında veya daha fazla tutulduğu olgularda, gelişmesi muhtemel bir patolojik kırık akla gelmelidir. Bazı durumlarda bu tutulumu direkt grafiden ölçmek zor olup, BT yardımı ile bu tutulumu ölçmek daha açık ve kesin bilgi verebilir. Cappana ve arkadaşlarının serisinde, femurda $2,5 \mathrm{~cm}$ ve üstünde olan tutulumlarda $\% 55$ oranında patolojik kırık gelişmiştir. ${ }^{[13]}$

4. Bunların dışında, uzun kemik metastazı olan herhangi bir olguda devam eden inatçı ağrılarda ve radyoterapi ve kemoterapi sonrası ağrısı geçmeyen hastalarda da patolojik kırık riskinin yüksek olacağı akılda tutulmalıdır.

Günümüzde onkolojik ortopedinin temel taşlarından olan Mirels'in skorlama sistemi, patolojik kırık gelişiminde; anatomik bölge, ağrı, radyolojik görünüm ve lezyonun büyüklüğü parametrelerinden oluşmaktadır.

Bu tabloya göre ortalama skoru 7 (4-9) olanlarda düşük patolojik kırık risk ve ortalama skoru 10 olanlarda da (7-12) ise yüksek kırık riski vardır (Tablo 3 ). 
Tablo 3. Mirels'in skorlama sistemi

\begin{tabular}{lccc}
\hline & & Risk Skoru & \\
\hline PARAMETRE & $\mathbf{1}$ & $\mathbf{2}$ & $\mathbf{3}$ \\
BÖLGE & ÜST EXTREMITE & ALT EKSTREMITE & PERITROKANTERIK BÖLGE \\
AĞRI & AZ & ORTA DÜZEY & AYAKTA IKEN \\
LEZYON & BLASTIK & KARIŞIK & LiTIK \\
ÇAP & $<1 / 3$ & $1 / 3-2 / 3$ & $>2$
\end{tabular}

\section{ANATOMIK BÖLGELERE GÖRE KEMIK METASTAZLARI}

\section{Üst ekstremite metastazları}

Tüm kemik metastazlarının yaklaşık \%20'si üst ekstremiteye olurken, bunların da \%50'si humerusa olmaktadır. Tedavi edilmemiş alt ekstremite metastazları hastayı yatağa mahkum eder; ihmal edilmiş humerus metastazları ise ciddi ağrıya ve hastanın elini kullanamamasına yol açar. Üst ekstremiteye metastaz en sıklıkla akciğere ve karaciğeredir. ${ }^{[13]}$ Humerus, metastatik hastalıkta uzun kemiklerde femurdan sonra ikinci sıklıkta görülür; üst $1 / 3$ 'lük kısım ve diyafız ise en sık tutulan kısmıdır. Saf litik metastazlar ve kortekste destrüksiyonun olması, kırık riskini \%50 oranlarına kadar çıkarır. ${ }^{[14]}$ Hastaların çoğunda eksternal irradyasyon, ağrı kontrolu ve kemik destrüksiyonunu durdurmada etkilidir. Humerus baş ve cerrahi boynundaki metastazlar standart endoprotezlerle ve aşırı dercede kemik kaybı bulunan metastazlar ise prostetik proksimal humeral replasman yöntemleri ile tedavi edilir. Humerustan sonra daha az sıklıkla skapula ve ön kol metastazları görülür ve bu metastazlar genellikle radyoterapi ve kemoterapi gibi cerrahi dışı yöntemlerle tedavi edilir. Humerusta kırık riski olan olgular veya komplet diyafız kırıkları, intramedüller çivi veya plak ile başarılı şekilde tedavi edilebilmektedir (Şekil 8). Rijid tespit için dual plak uygulaması stabiliteyi arttırır. Kemik defekti ile birlikte olan olgularda metilmetakrilat kullanılması tespiti sağlamlaştııır. Humerus metastazlarında cerrahi tespit sonucu radyoterapi uygulanmayan olgulardan \%15-20'sinde hastalıkta ilerleme ve tespit kaybı görülmektedir. ${ }^{[15]}$

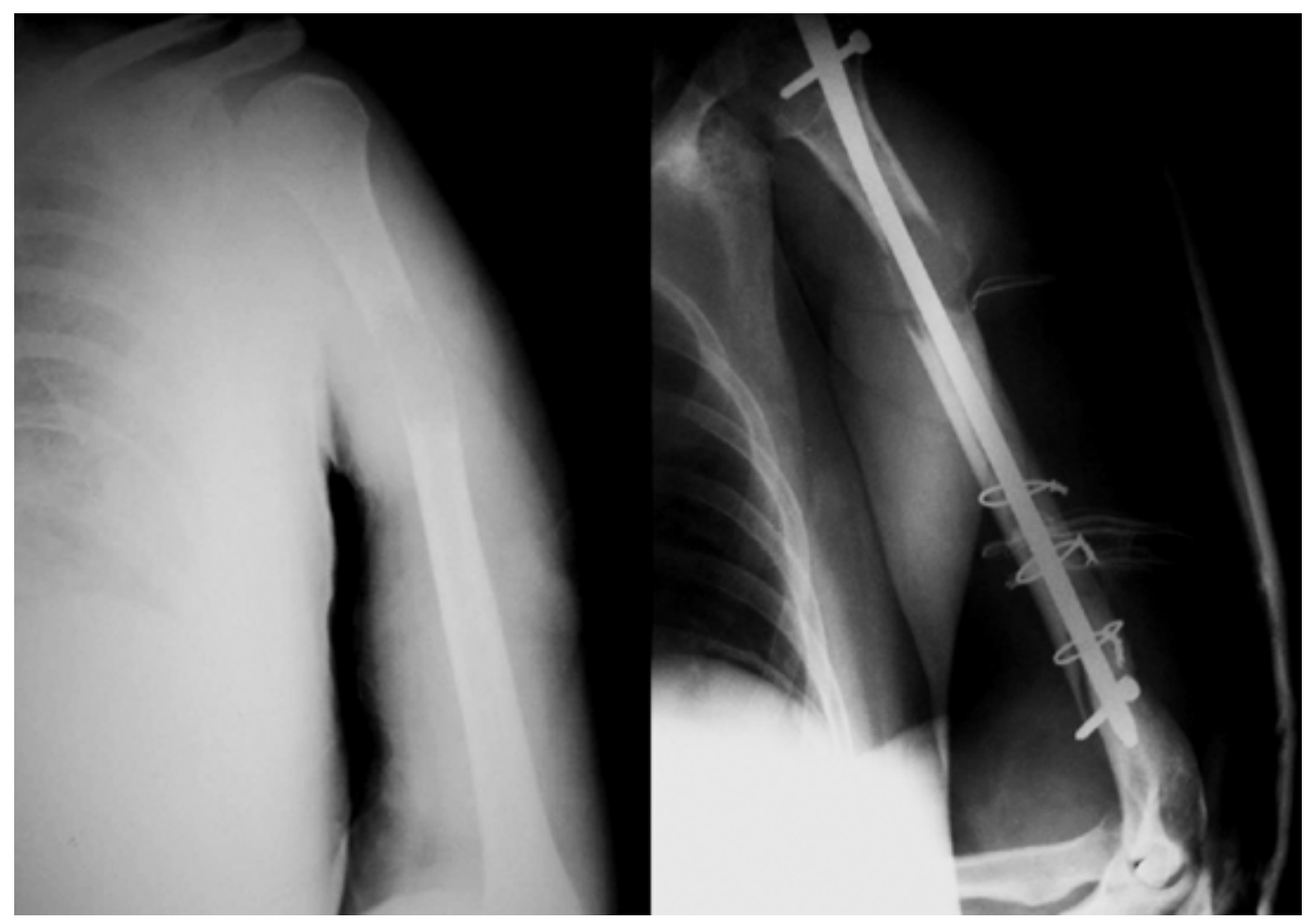

Şekil 8. Sağ humerus diyafizinde, meme karsinomuna bağlı metastaza bağlı gelişen patolojik kırığın intramedüller çivileme ile tedavi edilmiş halinin direkt grafi görüntüsü. 


\section{Alt ekstremite metastazları}

Kemik metastazlarında pelvis ve proksimal femur, omurgadan sonra sık tutulan kemiklerdir. ${ }^{[16]}$ Metastatik tutulum; vertebrada \%69 (sıklıkla anterior ve orta kolon), pelviste $\% 41$, femurda $\% 25$ ve kraniyumda $\% 14$ olarak bulunmuştur. ${ }^{[17]}$.

Proksimal femur, appendiküler iskelette en sık kemik metastazının görüldüğü yerdir. Patolojik kırık proksimal femurda oldukça sıktır. Bunların \%50'si femur boynunda, \%30'u subtrokanterik bölgede ve \%20'si intertrokanterik bölgededir. Proksimal femurdaki patolojik kırıklar, bozulmuş mobilite, bozulmuş fonksiyon ve azalmış yaşam kalitesine neden olur.

Tibia metastazları son derece nadir olup alt ekstremite metastazlarının yaklaşık 5\%'ini oluşturur ve tedavide oldukça agresif yaklaşımlar gerektirir. ${ }^{[18]}$ Dizin altındaki ayak bölgesinde iskelet bölgesinin metastazları ise son derece (\%1 civarında) nadir olup, bu gibi durumlarda akciğer ve böbrek hücreli karsinom ve kolon akla gelmelidir (Şekil 9). ${ }^{[19]}$

\section{Vertebral metastazlar}

Akciğer ve kolondan sonra üçüncü en sık metastaz bölgesidir. Otopsi çalışmalarına göre tüm kanser olgularının, değişen oranlarda olmak üzere, \%30 ile \%90'ında omurgaya metastaz gelişir, fakat bunların yaklaşık \%20-30'u semptomatiktir. Bu olguların da \%20'si medulla spinalis basısına neden olur. MD Anderson Kanser Merkezi verilerine göre, omurga metastazlarının \%60'ı meme, akciğer ve prostat kanserinden kaynaklanır. Olguların \%80'inde vertebra korpusu tutulur. En sık metastaza maruz kalan bölge ise yaklaşık \%70'lik bir oranla torakal bölgedir. ${ }^{[20,21]}$ Akciğer kanserinde vertebral metastaz direkt vertebral segmental arter ile olurken, meme ve prostat kanserleri Batson plexusu ile metastaz yapar (Şekil 10). ${ }^{[22]}$

Tokuhashi ve arkadaşları, metastatik omurga tümörleri için prognoz ve yaşam beklentisini belirlemek için bir değerlendirme sistemi geliştirmiştir. ${ }^{[23]} \mathrm{Bu}$ sistemde, altı parametrenin değerlendirilmesi ile elde edilen toplam skor, tedavi planlamasını yönlendirir.

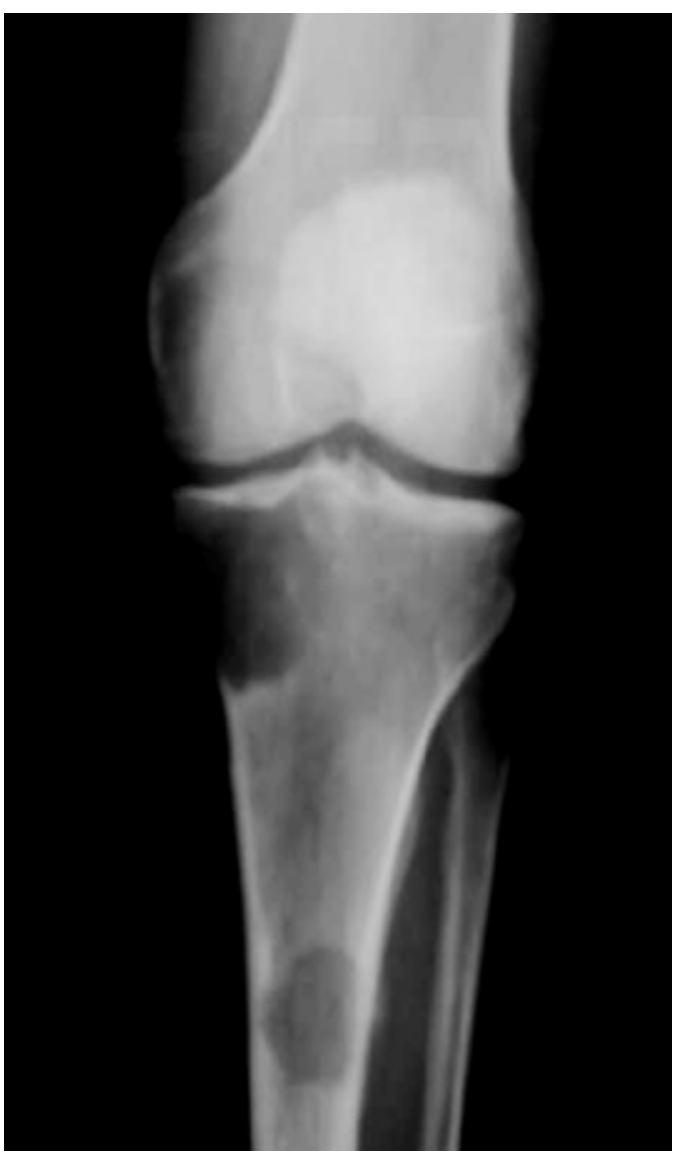

Şekil 9. Tibia proksimal metafizer ve metafizodiyafizer yerleşimli böbrek hücreli karsinom metastazının direkt grafisi.

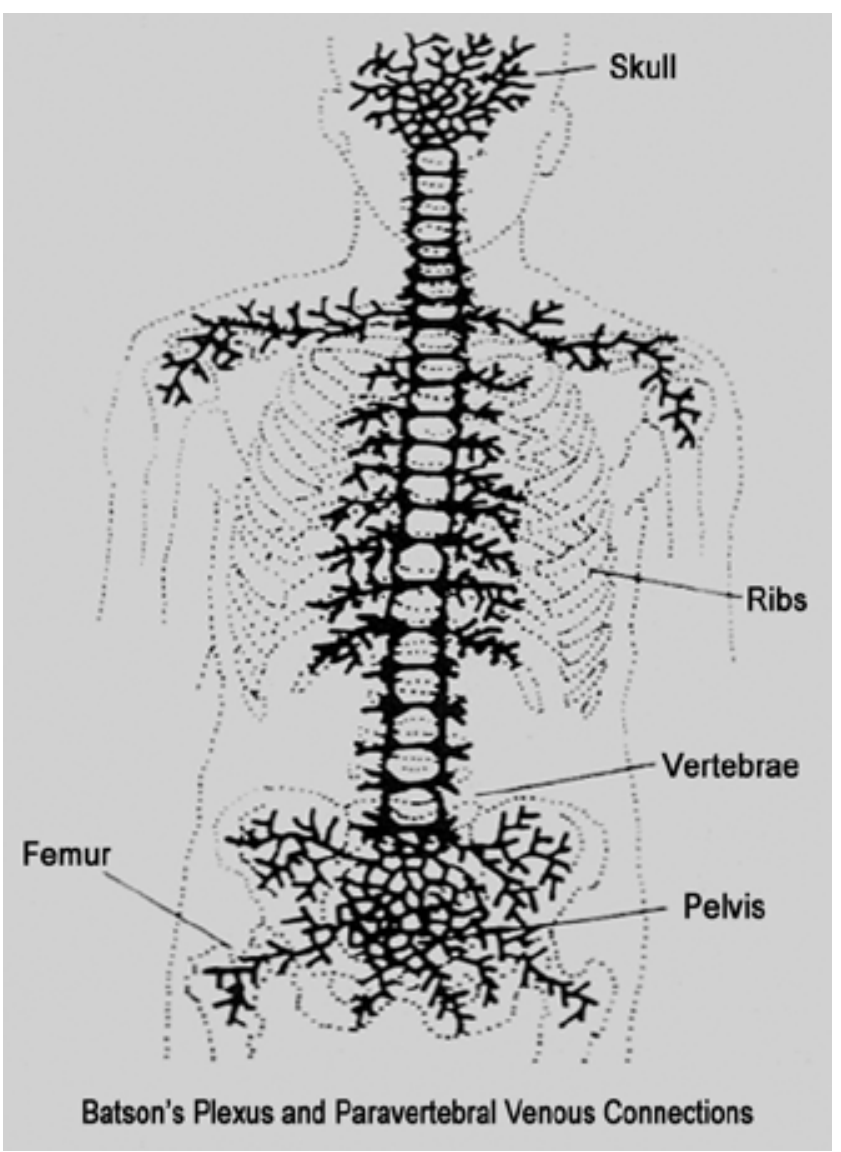

Şekil 10. Baston venöz pleksusu ile vertebral-paravertebral venöz bağlantılar vasıtası ile prostat ve omurga kemikleri arasında metastaz yayılımının şematik gösterimi. 
Buna göre hastanın toplam skoru 0-8 arasındaysa 6 aydan az, 9-11 arasındaysa 6 aydan fazla, 12-15 arasındaysa 1 yıldan fazla yaşayacağı öngörülür. Toplam skoru 8 ve altında olan hastalarda konservatif yöntemler ya da palyatif cerrahi yaklaşımlar tercih edilir. Eğer skor 12 ve üzerindeyse eksizyonel girişimler seçilir.

Tomita ve arkadaşları prognozu değerlendirmek için daha basit bir sistem önermişlerdir. ${ }^{[24]}$ Buna göre üç prognostik etmenin değerlendirilmesi sonucunda elde edilen toplam skor ile tedavi yaklaşımı belirlenir (Tablo 4). Tomitanın skorlama sistemi, tümörün büyüme hızı, viseral metastaz durumu ve kemik metastazına bağlı olarak tedavi hedefi ve cerrahi stratejinin belirlendiği bir sistemdir.

1. Malignensinin evresi: yavaş ilerleyen, 1 puan; orta hızda ilerleyen, 2 puan; hızı ilerleyen, 4 Puan.

2. Organ metastazı: metastaz yok, 0 puan; var ama tedavi edilebilir, 2 puan; var ama tedavi edilemez, 4 puan.
3. Kemik metastazı: tek metastaz, 1 puan; çoklu metastaz 2 puan.

Toplam skoru 4-5 olan hastalarda, orta dönemde lokal kontrol amaçlandığından, marjinal ya da intralezyonel eksizyon önerilir. Skoru 6-7 puan olan olgularda, kısa dönem palyasyon amaçlandığından, palyatif tedavi önerilir. Puanı 8-10 olan hastalar terminal dönem kabul edildiğinden, cerrahi tedavi önerilmez ve sadece destekleyici tedavi uygulanır. ${ }^{[25]}$

Son yıllarda gelişen cerrahi tekniklerle, omurga metastazlarında cerrahi yaklaşım tek başına tümörün eksizyonu olmaktan çıkmıştır. Eğer yaşam beklentisi fazlaysa daha radikal cerrahiler uygulanabilir (Şekil 11). Metastaza bağIı tutulumlarda primer tümörün ortalama yaşam süresinin bilinmesi tedavi planı yaparken yararlı olur (Tablo 5).

Vertebra metastazlarında ortalama yaşam süresi ile uygulanacak tedavi yöntemi yakın korelasyon gösterir. Cerrahi tedavinin planlandığı olgularda primer tümöre göre değişmekle birlikte, en az altı aylık bir sağkalım gerektiği düşünülür.

Tablo 4. Tomitanın skorlama sistemi

\begin{tabular}{|c|c|c|c|c|c|c|}
\hline \multicolumn{4}{|c|}{ Scoring system } & \multirow{2}{*}{$\begin{array}{c}\begin{array}{c}\text { Prognostic } \\
\text { score }\end{array} \\
\end{array}$} & \multirow{2}{*}{$\begin{array}{c}\text { Treatment } \\
\text { goal }\end{array}$} & \multirow{2}{*}{$\begin{array}{l}\text { Surgical } \\
\text { strategy }\end{array}$} \\
\hline \multirow[b]{2}{*}{ Point } & \multicolumn{3}{|c|}{ Prognostic factors } & & & \\
\hline & $\begin{array}{l}\text { Primary } \\
\text { tumor }\end{array}$ & $\begin{array}{c}\text { Visceral } \\
\text { mets.a }\end{array}$ & $\begin{array}{l}\text { Bone } \\
\text { mets. }\end{array}$ & $\begin{array}{l}2 \\
3 \\
\end{array}$ & $\begin{array}{c}\text { Long-term } \\
\text { local control }\end{array}$ & $\begin{array}{l}\text { Wide or } \\
\text { marginal } \\
\text { excision }\end{array}$ \\
\hline 1 & $\begin{array}{c}\text { Slow } \\
\text { growth } \\
\text { (breast, thyroid, } \\
\text { etc.) }\end{array}$ & & $\begin{array}{l}\text { Solitary } \\
\text { or } \\
\text { isolated }\end{array}$ & 4 & $\begin{array}{l}\text { Middle-term } \\
\text { local control }\end{array}$ & $\begin{array}{l}\text { Marginal or } \\
\text { intralesional } \\
\text { excision }\end{array}$ \\
\hline 2 & $\begin{array}{l}\text { Moderate } \\
\text { growth } \\
\text { (kidney utherus. } \\
\text { efo.) }\end{array}$ & Treatable & Multiple & 6 & $\begin{array}{l}\text { Short-term } \\
\text { local control }\end{array}$ & $\begin{array}{l}\text { Palliative } \\
\text { surgery }\end{array}$ \\
\hline 4 & $\begin{array}{l}\text { Rapid } \\
\text { growth } \\
\text { (lung. atomach. }\end{array}$ & Untreatable & & $\begin{array}{l}8 \\
9 \\
10\end{array}$ & $\begin{array}{l}\text { Terminal } \\
\text { care }\end{array}$ & $\begin{array}{c}\text { Supportive } \\
\text { care }\end{array}$ \\
\hline
\end{tabular}

Tablo 5. Vertebra metastazlarında ortalama yaşam süresi

\begin{tabular}{lc}
\hline Primer tümör & Ortalama yaşam süresi (ay) \\
\hline Akciğer CA & 4 \\
Meme CA & $24-36$ \\
Prostat CA & $>48$ \\
Renal Hücreli CA & $>12-13$ \\
Tiroid CA & $>48$ \\
Lenfoma/Miyelom & $>48$ \\
Melanoma & 4 \\
Sarkoma & $8-12$
\end{tabular}




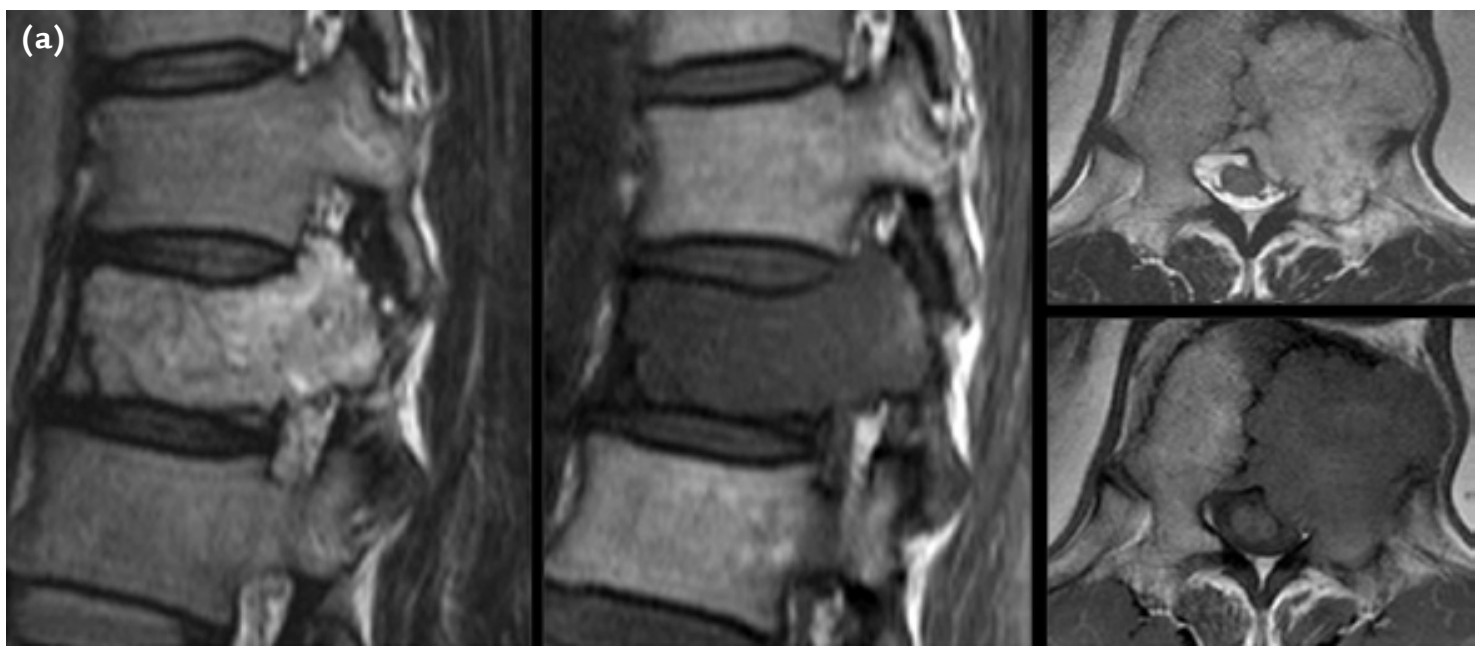

(b)
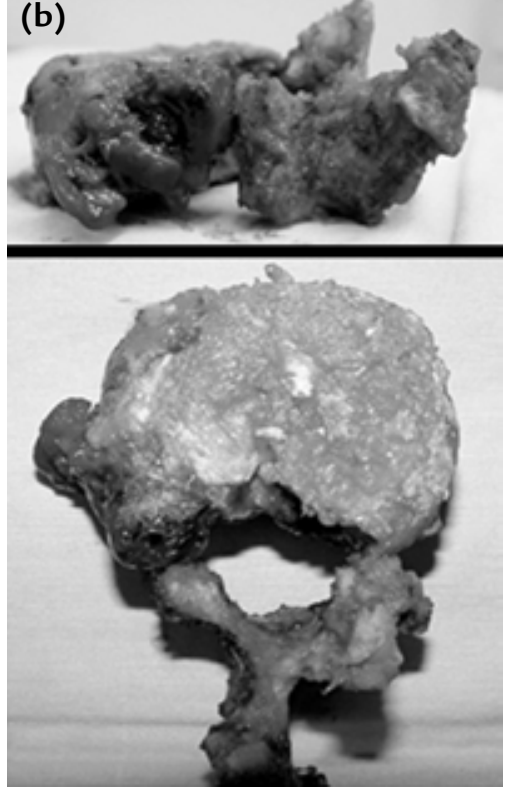

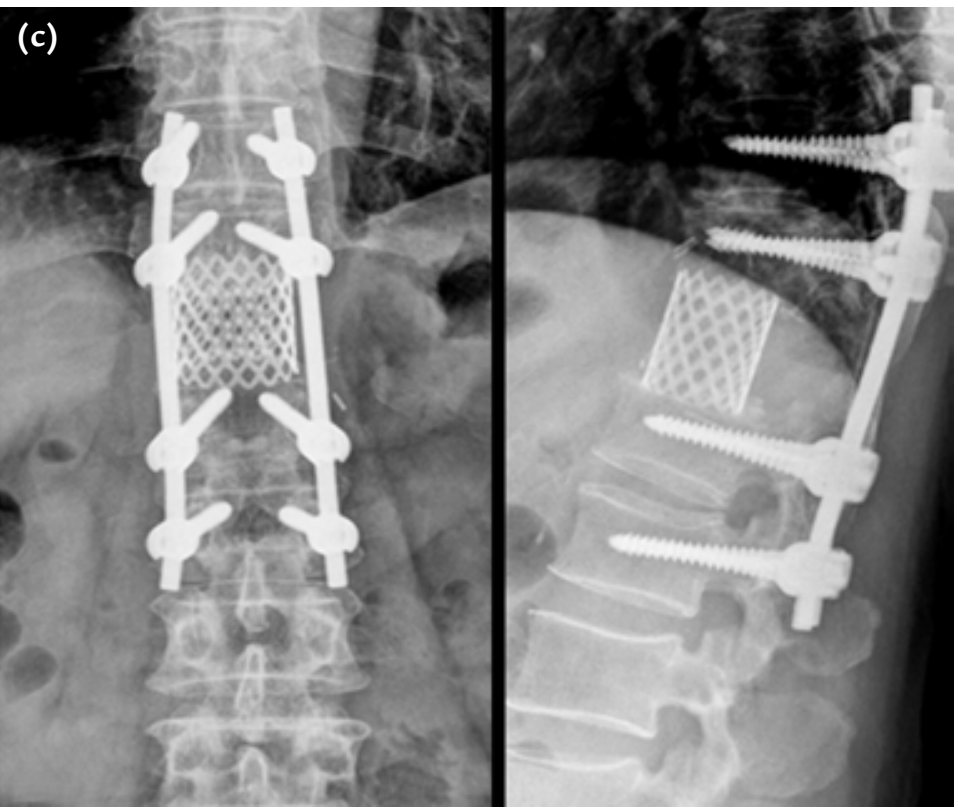

Şekil 11. Korpektomi, kafes uygulaması ve posterior enstrümantasyon ile cerrahi tedavisi yapılmış metastatik bir vertebra tümörünün ameliyat öncesi MR ve ameliyat sonrası direkt grafileri.

Omurga metastazı olan her hastada cerrahi tedavi endikasyonu yoktur. Aşağıdaki nedenlerden herhangi biri varsa cerrahi endikasyonu vardır:

- Kord disfonksiyonu ile beraber olan epidural bası.

- Spinal instabilite.

- Medulla spinalise kemik bası.

- Tanı koymak için.

- Konservatif tedaviye rağmen geçmeyen ağrı.

- Radyoterapiye dirençli tümörler.

- Radyoterapiye rağmen nüks.

- Radyoterapi sırasında nörolojik bulguların kötüye gitmesi.

\section{KEMIK METASTAZLARINDA GENEL TEDAVi PRENSIPLERI}

Kemik metastazlarında cerrahi tedavi çok nadir durumlarda gerekir; radyoterapi, kemoterapi veya ikisi birlikte çoğu zaman semptomatik rahatlama sağlar. Kemikte patolojik kırıklar nadir olarak kendiliğinden iyileşebileceği için bu durumlarda açık tespit gerekir. Cerrahi tespitin amacı; ağrıyı geçirmek, fonksiyonu korumak, hastayı ambulatuvar hale getirmek, hastanın bakımını ve iyi olma halini sağlamaktır. Hastanın ayağa kaldırma durumunu sağlamayacak ise cerrahiden kaçınmamız gerekir. Cerrahi sonrası yara iyileştikten sonra, lokal tümör büyümesini baskılamada, kemik tamirine olanak sağlamada ve tespit materyali çevresinde tümörün yeniden büyümesini önlemede radyoterapi tercih edilir. ${ }^{[26]}$ 
Günümüzde iskelet metastazlarında tedavinin ana hatları:

- Ağrı tedavisi / analjezikler.

- Sistemik tedavi ajanları (kemik modifiye edici ajanlar, kemoterapi, hormon tedavileri).

- Radyasyon tedavisi (external beam radiotherapy EBRT, radyofarmakoterapötikler).

- Cerrahi.

Kemik metastazlarında optimal tedavi son derece karmaşık olup, cerrahi, radyoterapi ve medikal onkoloğun radyolog ve patolog ile birlikte takım çalışmasını gerektirir. Kemik metastazlarında tanının erken konulması ve agresif olarak tedaviye başlanması yaşam kalitesi ve fonksiyonel yeteneklerin korunmasında çok önemlidir. ${ }^{[27]}$

Kemik metastazlarında, asemptomatik lezyonlarda sadece klinik ve radyolojik takip yapılabilir. Bu lezyonlar; bifosfonat tedavisi, radyoterapi ve alttaki hastalığın tedavisi ile başarılı bir şekilde izlenebilir.

\section{CERRAHI TEDAVi}

Cerrahi, yük taşıyan bir kemikte ağrılı kemik lezyonlarında radyoterapiye yanıt alınamadığı durumlarda veya yüksek patolojik kırık riski durumlarında endike olur. Cerrahi tedavide en kesin endikasyon ise, yük taşıyan bir kemikte patolojik kırık gelişimidir. Metastaz cerrahisinde seçilecek implant; hastaya, tümörün biyolojisine, radyoterapiye cevabına ve lezyonun anatomik lokalizasyonuna uygun olarak seçilmelidir. Örneğin Gainor ve arkadaşlarının yaptı̆̆ bir çalışmada, patolojik kırıkların kemiksel kaynama oranları incelenmiş ve tümörün tipine göre, \%67 ile en yüksek kaynama oranının multipl miyelom'da ve en düşük kaynama oranının ise, nerdeyse hiç kaynama görülmemesi ile, akciğer kanserlerinde olduğu gözlenmiştir. ${ }^{[28]}$

Metastaz tanısının histolojik olarak kesinleştirilmesi mutlaka gerekir. Histolojik olarak primer bir karsinomu olan hastada yaygın iskelet metastazları varlığında ise, kemikten biyopsi almadan tedaviye başlanabilir. Kemik metastazı ile başvuran, biyopsi ile frozen section yardımıyla metastatik karsinom tanısı konulan hastalarda, kesi genişletilerek cerrahi tespit aynı seansta uygulanabilir; aksi takdirde, eğer kesin tanı konulamıyorsa, tanı konulana kadar kesinlikle cerrahi uygulanmamalıdır.

Sonraki aşamada, metastaza bağıı olarak, kemikteki kayıp miktarına, yumuşak doku infiltrasyonuna ve alttaki tümörün doğal öyküsüne göre:

- açık tespit,

- endoprotestetik rekonstrüksiyon/artroplasti işlemleri uygulanır.
Tümörün çok hızlı büyüdüğü ve adjuvan radyoterapinin göreceli olarak etkisiz olduğu durumlarda (renal hücreli karsinom gibi) cerrah, kemikten standarda göre daha fazla cerrahi rezeksiyon yapmayı düşünmelidir. Bu gibi durumlarda amaç, lokal rekürrens gelişme riskini ve morbiditeyi azaltmaktır.

Açık tespitlerde birçok stabilizasyon prosedürü, uzun bir intramedüller rod veya plak-vida rekonstrüksiyonunu içerir. Plak-vida rekonstrüksiyonu, ekstramedüller bir sistemdir ve yük taşıma amaçlı olarak kemiğin mediyal veya lateral kenarına tespit edilir. Strüktürel defekte bağlı olarak gelişen kemik kayıplarının tedavisinde, bu kaviteler polimetimetakrilat veya metal ile etkin bir şekilde güçlendirilir. Bu bölgelerdeki tümöral doku makroskopik tümör kayboluncaya kadar kürete edilir ve oluşan kavite polimetimetakrilat ile doldurularak mekanik stabilite sağlanır.

Metastaza bağlı oluşan kemik defektlerinde kadaverik kemik greftleri nadiren gerekir, çünkü iyileşme süresi uzar ve yük verme kısıtlanır, ayrıca cerrahi sonrası uygulanacak radyoterapi kemiksel yeniden şekillenme ve greftin kemiğe inkooperasyonunu baskılar.

Periartiküler lezyonlarda ve aşırı kemik kaybı olan metastatik tutulumlarda rezeksiyon veya endoprotestik artroplastiler tercih edilmelidir (Şekil 12).

Ampütasyon, iskelet metastazlarında çok nadir uygulanan bir cerrahi yöntemdir; fakat kemik metastazının aşırı yumuşak doku ile birlikte olduğu, yaşamsal damar-sinir paketini tuttuğu durumlarda ve hiçbir şekilde geçirilemeyen ağrı durumlarında uygulanabilir (Şekil 13).

\section{ALT EKSTREMITE METASTAZLARININ TEDAVISINE GENEL YAKLAŞIM}

Alt ekstremitenin metastatik tümörlerinde semptomatik ve destrüktif lezyonlarında iki türlü tedavi yaklaşımı vardır:

1. Cerrahi dışı tedavi: bu tedavide hastaya uzun süreli yatak istirahatı, yük vermeme ve yürüteç veya koltuk değnekleri önerilir. Aralıklı radyoterapi ile semptomatik düzelmeler sağlanır ve ağrı geçerse hastaya uyarılar verilerek yük verdirilebilir.

2. Cerrahi tedavi: anatomik bölgeye göre değişkenlik gösterir.

\section{Asetabulum}

Periasetabular lezyonlar genellikle çok delikli cup'lar, kafesler, kemik çimentosu ve pin'lerden oluşan implantlarla birlikte kalça rekonstrüksiyonları şeklinde 


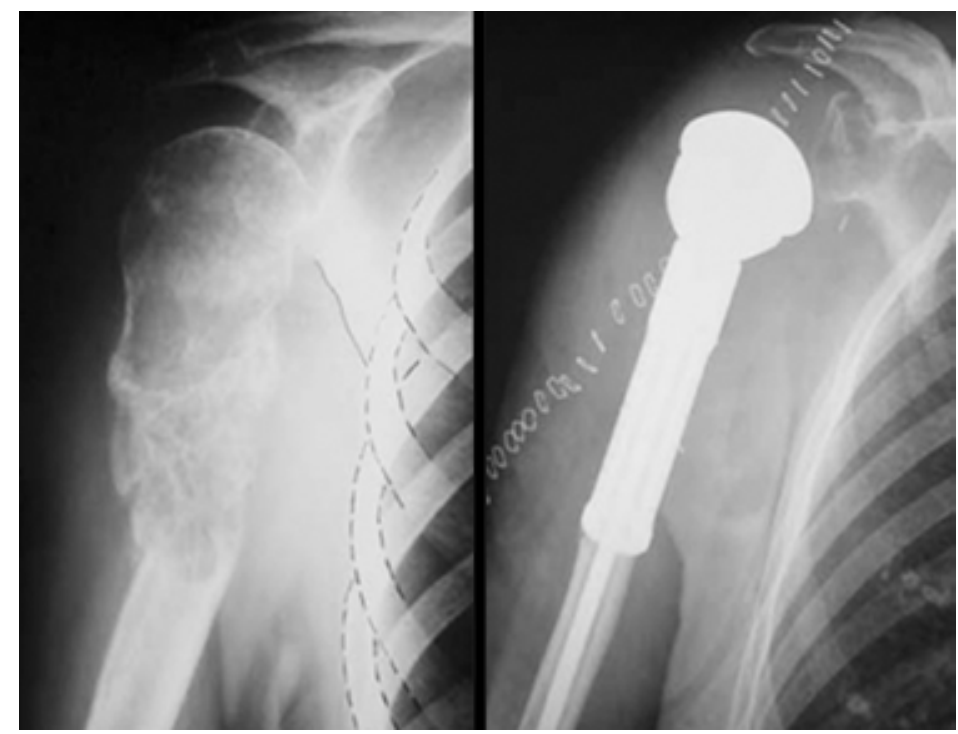

Şekil 12. Sağ humerus üst uçta böbrek hücreli kanser metastazına bağlı olarak patolojik kırık gelişmi ve geniş rezeksiyon sonrası modüler tümör protezi ile rekonstrüksiyon.

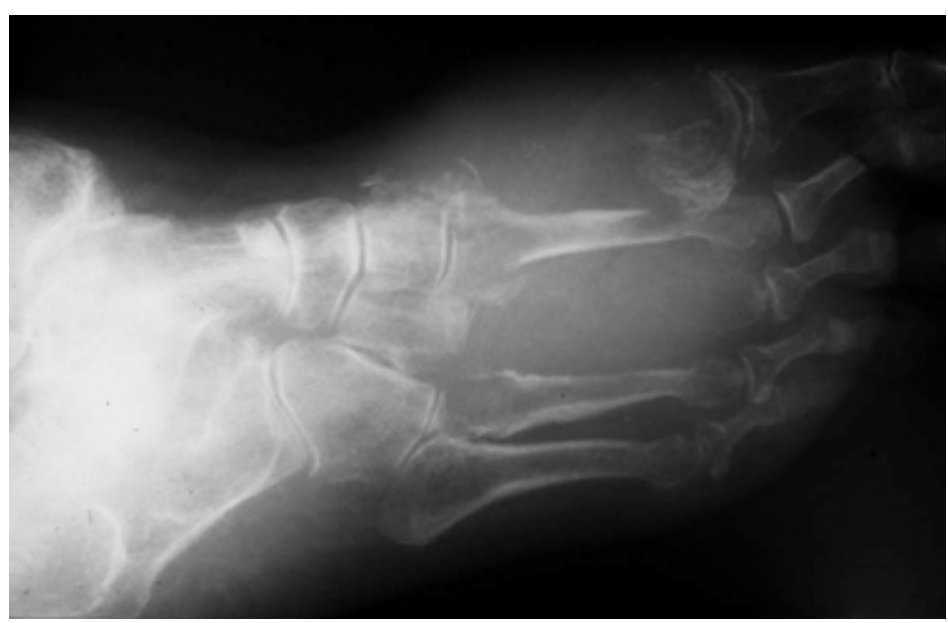

Şekil 13. Ayak kemiklerinde metastazı olan 94 yaşında bir kadın hasta dayanılmaz ağrı ve fonksiyon kaybı nedeniyle ampütasyon ile tedavi edilmiştir.

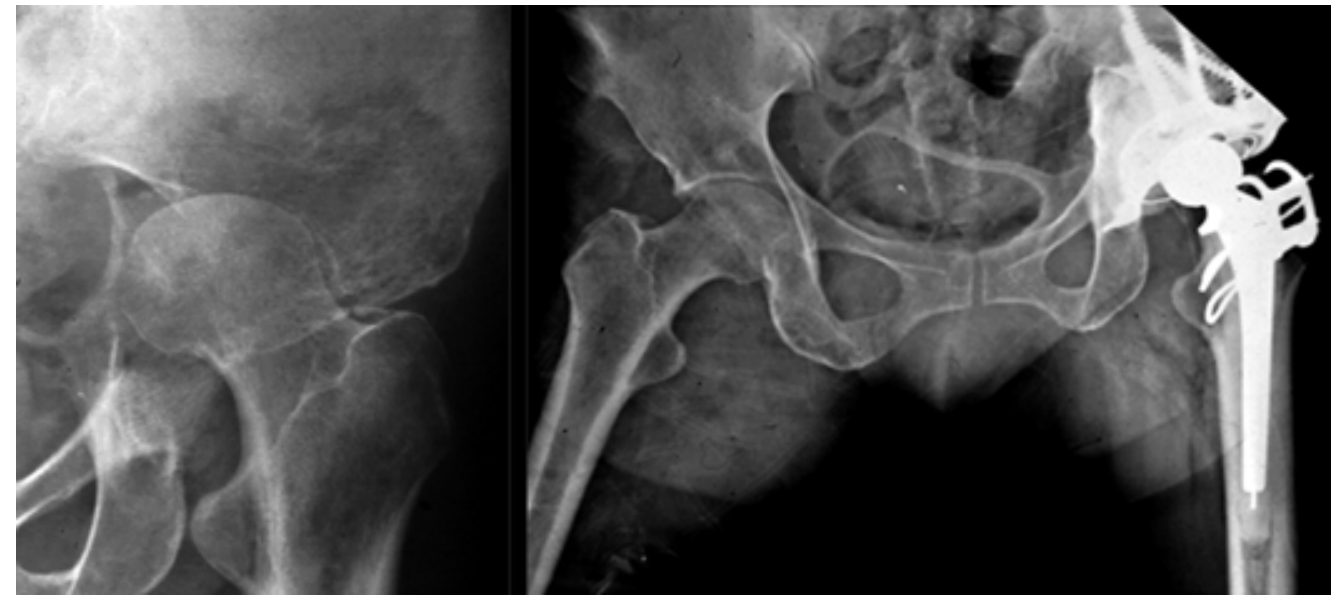

Şekil 14. Renal hücreli karsinoma bağlı gelişen sol asetabular bölgeye ait metastazın çimentolu asetabular kafes, çoklu Steinmann pinleri ile yapılan rekonstrüksiyonu. 
artroplastiler ile tedavi edilir (Şekil 14). Aşırı derecede periasetabular defekti olan metastazlarda, alt ekstremite güçlerinin omurgaya iletilemediği durumlarda, pelvis rekonstrüksiyonu gerekmektedir.

\section{Femur}

Femur tutulumlarında cerrahi tedavi, tutulum yeri ve yaygınlığına bağlı olarak değişir. Femur baş ve boyun tümörleri, internal tespitin yüksek başarısızlık oranı nedeniyle, artroplasti ile olmaktadır (Şekil 15) ve asetabulumun tutulmadığı durumlarda hemiartroplasti yetersiz kalmaktadır; femoral stem tercihen çimentolu olmalıdır. Multifokal femoral tutulumlarda mutlaka uzun stem tecih edilmelidir; fakat bunun da çimentolama aşamasında embolizasyon riskini arttırdığı unutulmamalıdır. Femoral diyafiz tutulumlarında femur boynu ve başını da tespit eden intramedüller çiviler tercih edilmelidir.

Distal femoral metafiz ve epifiz metastazlarında; tümörün küretajı, çimentolama ve plak vida tespiti tercih edilmekle beraber, kemik kaybının aşırı olduğu durumlarda diz artroplastisi veya distal femoral replasman tercih edilmelidir.

\section{Tibia}

Tibia metastazlarında tedavi seçenekleri Kelly ve arkadaşları tarafından iyi tanımlanmıştır. ${ }^{[18]}$ Proksimal tibial metafiz ve epifiz metastatik tümörleri distal femur gibi tedavi edilirken, geniş kemik kaybı ile birlikte olan eklem çevresi destrüksiyonları artroplasti gerektirir. Tibia diyafiz tutulumları, proksimal ve distalde yeterli kemik stoğunun olduğu durumlarda, kilitli çivilerle tedavi edilir. Distal tibiadaki izole defektler, küretaj, çimento ve internal plak ile tespit edilir. Çok nadir, kemik kaybının aşırı ve yumuşak doku tutulumunun yaygın olduğu durumlarda, ampütasyona geçilebilir.

\section{ÜST EKSTREMITE METASTAZLARI}

Üst ekstremite metastazlarında yük taşımayı yasaklamak çok daha kolaydır. Bu yüzden üst ekstremite ağıılı metastazlarında, tedavide ilk aşamanın omuz askısı ile immobilizasyon ve palyatif ışın tedavisi olması mantıklıdır. Eğer hasta, metastazından dolayı koltuk değneği veya başka ambulasyon cihazlarına ihtiyaç duyuyorsa, proflaktik cerrahi girişim gerekir. Cerrahi tedavi, diğer bölgelerde olduğu gibi tutulum yeri ile ilgilidir. Baş ve boyun metastazları omuz hemiartroplastisi ile tedavi edilirken, bu bölgenin kemik kaybı ile birlikte olan epifiz ve metafiz metastazlarında çivi veya plak yetersiz kalacak ve yeterli tespit sağlayamaz. Humeral metastazlarda, uzun stem tümör ilerlemesi ve yayılmasını önlemek için çimentolu olarak uygulanmalıdır.

Kemik kaybının aşııı olduğu durumlar ile metafizer ve epifizer tutulumun ön planda olduğu durumlarda, proksimal humerus megaprotezi ile rekonstrüksiyon uygundur. Prostetik başın kalan yumuşak dokuya dikilmesi stabiliteyi arttırır. Bu rekonstrüksiyon, omuz hareketlerini sağlamaktan ziyade, omuzu yukarıda

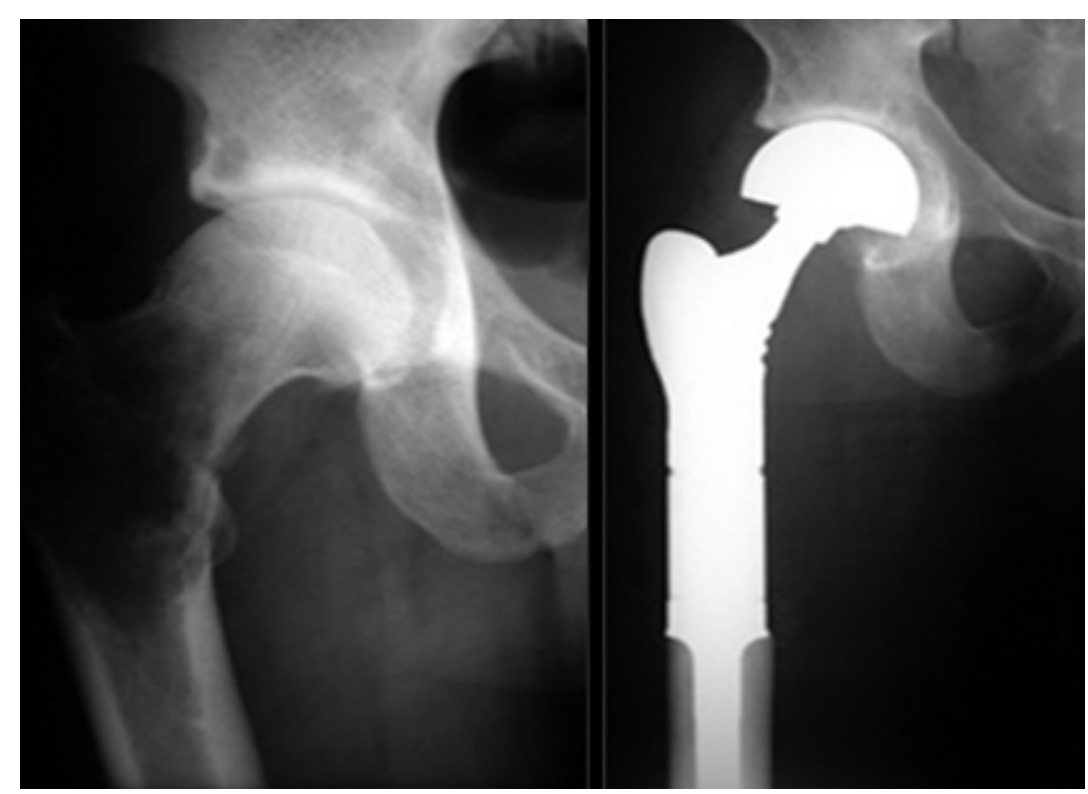

Şekil 15. Sağ femur trokanterik bölgede akciğer karsinomuna bağlı olarak gelişen metastazın, tümör rezeksiyon protezi ile tespiti. 
asarak fonksiyonel dirsek, el bileği ve el hareketlerini sağlamada etkili olur. Hastalar ameliyat öncesinde, cerrahi sonrası gelişecek omuz hareket kısıtlılığı açısından uyarılmalıdır.

Intramedüller humerus diyafizer tutulumları, intramedüller çivi ve plakla tespit edilmelidir. Bu tekniğin avantajı, tüm kemiği küçük bir insizyonla stabilize etmektir. Dezavantajı ise, proksimalden distale doğru uygulanırken rotator kılıfa zarar verilme olasılığıdır ve durum cerrahi sonrası geçmeyen ağrılara neden olur. Plak ile internal tespitte ise avantaj olarak, rotator kılıfın korunması ve aynı insizyonla hem küretaj hem de tespitin yapılabilmesi sayılabilirken, uzun insizyon ve fazla yumuşak doku sıyrılma gereksinimi nedeniyle kanamanın artması dezavantaj olarak dikkate alınmalıdır. Buna ek olarak, radyal sinirin dönme bölgesinde zedelenebilmesi dezavantajlar arasındadır.

Distal humerus metafiz ve diyafiz tutulumlarında en iyi yöntem, plak ile tespittir, çünkü bu bölgede distal humerus olekranona doğru yassılaşarak mediyal ve lateral kondillere ayrilır ve bu anatomik bölge intramedüller çivi için uygun olmaz.

Humerusun tüm kemik boyunca yaygın metastatik tutulumlarında, hastanın performans durumunun iyi olduğu durumlarda, bir bütün olarak humerusun çıkarılması ve total humerus protezi ile rekonstrüksiyon yapılma zorunluluğu ortaya çıkar (Şekil 16).

\section{RADYOTERAPi}

Hastaların çoğunda, eksternal radyoterapi, lokalize metastatik kemik ağrılarında mükemmel palyasyon sağlar. Birçok klinik çalışmada, fraksiyone olarak planlanan yaklaşık beş doz tedavi ile bu palyasyon sağlanabilirken randomize klinik çalışmalara göre 8Gy'lik tek doz fraksiyone ağrı palyasyonunda yeterli olur. ${ }^{[29]}$ Günümüzde, Strontium 89 gibi radyofarmakotiklerin prostat kanserine ve bazı yayınlara göre ise meme kanserine bağlı olan metastatik tutulumlarda geniş saha radyoterapisi kadar etkili olduğu bildirilmektedir. ${ }^{[30]}$ Radyasyon onkolojisindeki son gelişmelere bakıldığında, Samarium 153'ün bir radyofarmosötik olarak meme ve prostat kanserine bağlı iskelet metastazlarında ayaktan hastalarda palyasyon sağlamada kullanılmaya başlandığı görülür. Bu ajanın, hastanın kemik ağrısı ve ağrı kesici kullanım miktarı üzerinde olumlu etkileri vardır.[31] Önümüzdeki yıllarda, radyoizotop tedavisinin yüksek doz bifosfonatlarla karşılaştırılmalı çalışmalarının yapılmasının, palyatif ağrı tedavisinde önemli olacağı düşünülmektedir.

\section{KEMOTERAPI - BIFOSFONATLAR}

Metastatik kemik tümörlerinde en önemli olan, tümörün patolojik tipidir. Örnek olarak bakıldığında, metastatik melanoma ve renal hücreli karsinomlarda sistemik kemoterapinin çok az etkisi olurken, lenfoma

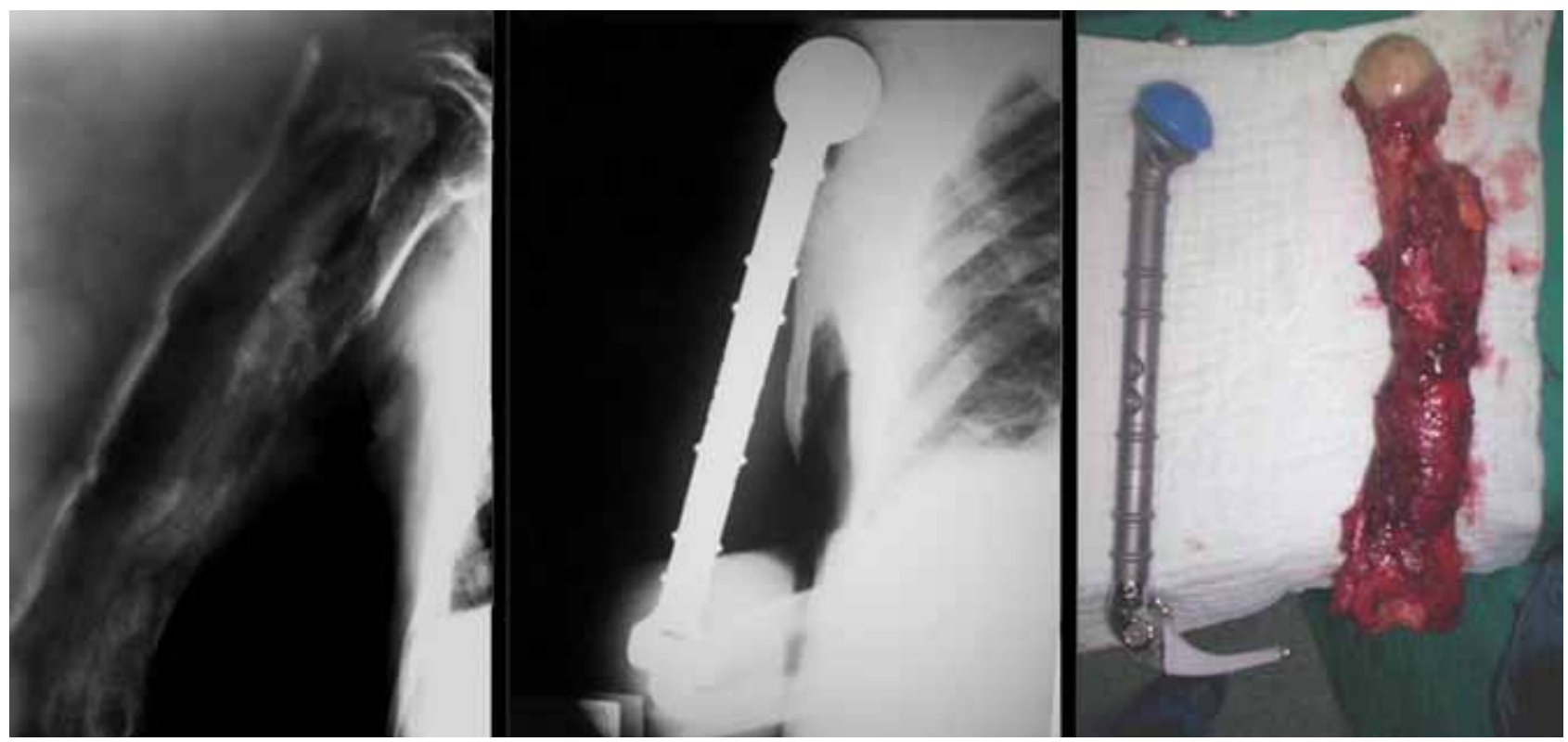

Şekil 16. Malign epitelyal tümör metastazına bağlı sağ humerusun tamamının yaygın kemik destrüksiyon ve kaybıyla etkilendiği bir olguda, rezeksiyon sonrası total humerus protezi ile rekonstrüksiyon. 
ve germ hücreli kemik tümörlerinde kombinasyon ilaç tedavisi küratif olabilir. Günümüzde, metastatik kemik tutulumlarında endokrin ve sitotoksik tedavilerde birçok gelişme ve yenilikler sağlanmıştır. Örneğin, meme kanseri kemik metastazlarında yeni yüksek spesifikli letrozol, anastrozol ve eksamestan gibi aromataz inhibitörleri, megestrol asetat, aminoglutethimide gibi eski ajanlara göre, çok daha iyi tolere edilebilmekle beraber, daha da etkili sonuçlar sağlamaktadır. Multipl miyelomda yüksek doz selektif kemoterapi ile birlikte uygulanan kemiki iliği ve periferik kök hücre desteği, sağkalımı anlamlı olarak uzatmıştır. Prostat kanserine bağlı kemik metastazlı hastalarda ise, kombine androjen bloke edici tedaviyle (LHRH) ile birlikte antiandrojen tedavinin, tek başına LHRH analoglarına göre daha etkili olduğu saptanmıştır.

Bifosfonat, ilk defa 1980'li yıllarda gündeme gelen, metastatik kemik yüzeyinde osteoklastlarla bağlanarak bölgedeki kemik yıkım işlemini biyokimyasal yolla bozarak etki eden ajandır. ${ }^{[32]}$ Tümör hücreleri üzerine direkt apoptotik etkisi de kanıtlanmış bir moleküldür. Klinik kullanımına bakıldığında, kemik metastazlarına bağlı gelişen hiperkalsemiyi düzeltmede başta gelmektedir ve metastatik hastalarda bifosfonat kullanımı, rehidratasyon ile birlikte $90 \%$ 'a varan başarılı sonuçlar rapor edilmiştir. ${ }^{[33]}$

Günümüzde iskelet sistem metastazlarında intravenöz yolla verilen pamidronat, clodronat, ibandronat, ve zoledronat gibi bifosfonatların etkisi, ağrı palyasyonunda randomize kontrollü çalışmalarda gösterilmiştir. Oral yolla verilen hiçbir bifosfonatın sistemik antikanser tedavisi olmadan kemik metastaz ağrısını azaltamadığı bilinir. Günümüzde yeni kuşak bifosfonatlar denildiğinde, aklımıza genellikle oral yolla verilen klodronat ve infüzyon yoluyla uygulanan pamidronat gelir.

Özet olarak, uzun dönem bifosfonat tedavisi, meme karsinomuna bağlı iskelet metastazlarında iskelet morbiditesini azaltmada, ağrının azaltılmasında ve ağı kesici ilaç kullanım miktarının azaltılmasında etkilidir. Bifosfonatlar, özellikle meme karsinomuna bağlı iskelet metastazlarında ve multipl miyelomda tedavinin rutin bir parçası olmuştur.

Henüz deneysel çalışma niteliğinde olan osteoklast inhibitörleri grubundan osteoprotogerin (OPG), farelerde kansere bağlı kemik yıkımında ve buna bağlı kemik ağrısını azaltmada denenmiş ve başarılı sonuçlar elde edilmiştir; yakında Faz 1 çalışmalar sonuçlanacaktır. ${ }^{[34]}$

Sonuç olarak kemiğe metastaz yapan bir tümörde tedavi; cerrahi tedavi, radyoterapi, kemoterapi veya radyokemoterapiye ulaşan geniş bir yelpazede değerlendirilip multimodal yaklaşım gerektiren bir antite olarak kabul edilmelidir.

\section{KAYNAKLAR}

1. Nielsen OS. Palliative radiotherapy of bone metastases: there is now evidence for the use of single fractions. Radiother Oncol 1999;52(2):95-6.

2. Roodman GD. Mechanisms of bone metastasis. N Engl J Med 2004;350(16):1655-64.

3. Robert J. Biology of cancer metastasis. Bull Cancer 2013;100(4):333-42. CrossRef

4. Smith HA, Kang Y. The metastasis-promoting roles of tumorassociated immune cells. J Mol Med (Berl) 2013;91(4):41129. CrossRef

5. Wedin R, Bauer HC, Skoog L, Söderlund V, Tani E. Cytological diagnosis of sketal lesions. Fine-needle aspiration biopsy in 110 tumours. J Bone Joint Surg Br 2000;82(5):673-8.

6. Bauer HC. Controversies in the surgical management of skeletal metastases. J Bone Joint Surg Br 2005;87(5):608-17.

7. Oliver TB, Bhat R, Kellet CF, Adamson DJ. Diagnosis and management of bone metastases. J R Coll Physicians Edinb 2011;41(4):330-8. CrossRef

8. Rougraff BT. Evaluation of the patient with carcinoma of unknown origin metastatic to bone. Clin Orthop Relat Res 2003; (415 Suppl):S105-9.

9. Söderlund V, Tani E, Skoog L, Bauer HC, Kreicbergs A. Diagnosis of skeletal lymphoma and myeloma by radiology and fine-needle aspiration cytology. Cytopathology 2001;12(3):157-67.

10. Stoker DJ, Cobb JP, Pringle JA. Needle biopsy of musculoskeletal lesions. A review of 208 procedures. J Bone Joint Surg Br 1991;73(3):498-500.

11. Merrick MV, Beales JS, Garvie N, Leonard RC. Evaluation and skeletal metastases. Br J Radiol 1992;65(777):803-6.

12. Frank JA, Ling A, Patronas NJ, Carrasquillo JA, Horvath K, Hickey AM, Dwyer AJ. Detection of malignant bone tumors: MR imaging vs scintigraphy. AJR Am J Roentgenol 1990;155(5):1043-8.

13. Capanna R, Campanacci DA. The treatment of metastases in the appendicular skeleton. J Bone Joint Surg $\mathrm{Br}$ 2001;83(4):471-81.

14. Muramatsu K, Ihara K, Iwanagaa R, Taguchi T. Treatment of metastatic bone lesions in the upper extremity: indications for surgery. Orthopedics 2010;33(11):807. CrossRef

15. Frassica FJ, Frassica DA. Evaluation and treatment of metastases to the humerus. Clin Orthop Relat Res 2003;(415 Suppl): S212-8.

16. Sim FH. Metastatic bone disease of the pelvis and femur. Instr Course Lect 1992;41:317-27.

17. Erler K. Metastatik Tümörlere Ortopedik Yaklaşım. TOTBiD Dergisi 2005;3-4:87-95.

18. Kelly CM, Wilkins RM, Eckardt JJ, Ward WG. Treatment of metastatic disease of the tibia. Clin Orthop Relat Res 2003;(415 Suppl): S219-29.

19. Leeson MC, Makley JT, Carter JR. Metastatic skeletal disease distal to the elbow and knee. Clin Orthop Relat Res 1986;(206):94-9.

20. Aebi M. Spinal metastasis in the elderly. Eur Spine J 2003;12 Suppl 2: S202-13.

21. Khan SN, Donthineni R. Surgical management of metastatic spine tumors. Orthop Clin North Am 2006;37(1):99-104.

22. Weinstein JN. Differential diagnosis and surgical treatment of pathologic spine fractures. Instr Course Lect 1992;41:301-15. 
23. Tokuhashi $Y$, Matsuzaki $H$, Oda $H$, Oshima $M$, Ryu J. A revised scoring system for preoperative evaluation of metastatic spine tumor prognosis. Spine (Phila Pa 1976) 2005;30(19):2186-91.

24. Tomita K, Kawahara N, Kobayashi T, Yoshida A, Murakami $\mathrm{H}$, Akamura T. Surgical strategy for spinal metastases. Spine (Phila Pa 1976) 2001;26(3):298-306.

25. Şenköylü A, Altun NŞ. Omurganın metastatik tümörlerine cerrahi yaklaşım. The Journal Of Turkish Spinal Surgery 2007;18(3).

26. Malawer M. Treatment of Metastatic Bone Disease. In: Musculoskeletal Cancer Surgery. Malawer MM, Sugarbaker PH, editors. Netherlands: Kluwer Academic Publishers; 2001. p.215-30.

27. Yu HH, Tsai $Y$, Hoffe SE. Overview of diagnosis and management of metastatic disease to bone. Cancer Control 2012;19(2):84-91.

28. Gainor BJ, Buchert P. Fracture healing in metastatic bone disease. Clin Orthop Relat Res 1983;(178):297-302.

29. Janjan NA. Radiation for bone metastases: conventional techniques and the role of systemic radiopharmaceuticals. Cancer 1997;80(8 Suppl):1628-45.
30. Lewington VJ, McEwan AJ, Ackery DM, Bayly RJ, Keeling $\mathrm{DH}$, Macleod PM, Porter AT, Zivanovic MA. A prospective, randomised double-blind crossover study to examine the efficacy of strontium-89 in pain palliation in patients with advanced prostate cancer metastatic to bone. Eur J Cancer 1991;27(8):954-8.

31. Resche I, Chatal JF, Pecking A, Ell P, Duchesne G, Rubens R, Fogelman I, Houston S, Fauser A, Fischer M, Wilkins D. A dose-controlled study of 153 Sm-ethylenediamin etetramethylenephosphate (EDT MP) in the treatment of patients with painful bone metastases. Eur J Cancer 1997;33(10):1583-91.

32. Rogers MJ, Watts DJ, Russell RG. Overview of bisphosphonates. Cancer 1997;80(8 Suppl):1652-60.

33. Coleman RE. Pamidronate disodium in the treatment and management of hypercalcaemia. Reviews in Contemporary Pharmacotherapy 1998;9:147-64.

34. Honore $P$, Luger NM, Sabino MA, Schwei MJ, Rogers SD, Mach DB, O'keefe PF, Ramnaraine ML, Clohisy DR, Mantyh PW. Osteoprotogerin blocks bone cancer-induced skeletal destruction, skeletal pain and pain-related neurochemical reorganisation of the spinal cord. Nat Med 2000;6(5):521-8. 